\title{
Anti-infective activity of immunomodulators
}

\author{
K. Noel Masihi
}

\section{Introduction}

Infectious diseases continue to impact human morbidity and mortality. Every individual is vulnerable to microbial infections regardless of socioeconomic status, gender, age group or ethnic background. There has been an explosion of international air travel with an estimated 2 billion passengers travelling on commercial airlines every year. The rapid expansion of globalization and mass tourism has facilitated the spread of disease-causing pathogens from one continent to another at unprecedented rates. This has led to an alarming increase in the number of infectious diseases. According to the World Health Organization, at least 40 new diseases have emerged over the past two decades, at a rate of one or more per year.

An epidemic in one corner of the world may only be hours away from becoming an impending threat elsewhere as was dramatically demonstrated at the beginning of 2009. Viruses such as the pandemic (H1N1) 2009 influenza virus, often labeled as swine influenza virus, and recent H5N1 avian influenza viruses have the capacity to cause global outbreaks in which persons worldwide are at risk for infection and illness. The WHO declared that pandemic (H1N1) 2009 influenza virus had reached pandemic proportions in summer 2009 and in autumn, some Northern hemisphere countries such as the USA declared it as a national emergency. Unprecedented vaccination programs against pandemic (H1N1) 2009 influenza virus were initiated in many EU countries and in North America. Historically, pandemic influenza viruses have caused millions of deaths; the 1918 influenza alone caused over 40 million deaths, more than occurred during the whole First World War. The public health authorities were completely taken by surprise in 2003 when the sudden and unexpected multi-country outbreak of severe acute respiratory syndrome, SARS, occurred. The unfolding tragedy of AIDS, particularly in many developing nations, has been vividly highlighted by the scientific and public media. Tuberculosis, malaria and other infections that caused ravages in the nineteenth century are once again resurgent. Several infectious agents, such as vector-borne West Nile virus in the USA, neurological variants of Creutzfeldt-Jakob disease in Europe, and resistant forms of bacteria in several countries have emerged as public health concerns over the past few years.

Antimicrobial drugs have been instrumental in saving the lives of millions of people worldwide. The effectiveness of many antibiotics is, however, being steadily eroded by the emergence of DRUG-RESISTANT microorganisms [1]. This is evidenced by the adverse effects on the control and treatment of deadly diseases caused by Mycobacterium tuberculosis and Plasmodium falciparum. Extensively DRUG-RESISTANT (XDR) strains of Mycobacterium tuberculosis (MDR$\mathrm{TB}$ and XDR-TB) are raising new challenges in developing countries. The acute respiratory infections in children, mostly caused by Pneumococci and Haemophilus influenzae, are becoming more drug resistant. Over 90\% of Staphylococcus aureus strains and about $40 \%$ of Pneumococci strains are resistant to penicillin, which was introduced in the 1940 s. An increasing prevalence of methicillin-resistant Staphylococcus aureus (MRSA), multidrug-resistant (MDR) and pandrug-resistant (PDR) Escherichia coli, Klebsiella pneumoniae, and Pseudomonas aerugino$s a$ is being encountered in the clinics; Salmonella typhi, Streptococcus pneumoniae, Enterococcus faecium, and Shigella dysenteriae have been also reported as MDR. Each year, about 25000 patients die in the EU from an infection with MDR bacteria, and these 
bacteria are causing extra healthcare costs and productivity losses of at least EUR 1.5 billion each year (European Medicines Agency report, 2009, see Selected websites). Crucial drug choices for the treatment of common bacterial, viral, parasitic, and fungal infections are becoming limited or even nonexistent in some cases in the current era of antimicrobial resistance [2]. This development has not been paralleled by an effective increase in the discovery of new medicines for most pathogens, and the rate of new antimicrobials approvals is steadily dropping. The struggle to control infectious diseases, far from being over, has acquired a new poignancy. Novel concepts acting as adjunct to established therapies are urgently needed.

The IMMUNE SYSTEM can be manipulated specifically by vaccination or non-specifically by IMMUNOMODULATION. Immunomodulators include both immunostimulatory and immunosuppressive agents.
This chapter concentrates on immunostimulatory agents capable of enhancing host defense mechanisms to provide protection against infections. Synonymous terms for immunomodulators include immunostimulants, immunoaugmentors, BIOLOGICAL RESPONSE MODIFIERS, or immunorestoratives. Their modes of action include augmentation of anti-infectious immunity by the cells of the IMMUNE SYSTEM, encompassing lymphocyte subsets, MACROPHAGES, DENDRITIC CELLS and NATURAL killer (NK) cells. Further mechanisms can involve induction or restoration of immune effector functions and tilting the balance towards cytokine pathways germane to protection.A diverse array of RECOMBINANT, SYNTHETIC, and NATURAL immunomodulatory preparations for prophylaxis and treatment of various infections are available today [3-6]. A concise mind-map of some of the immunomodulators discussed in this chapter is summarized in Figure 1.

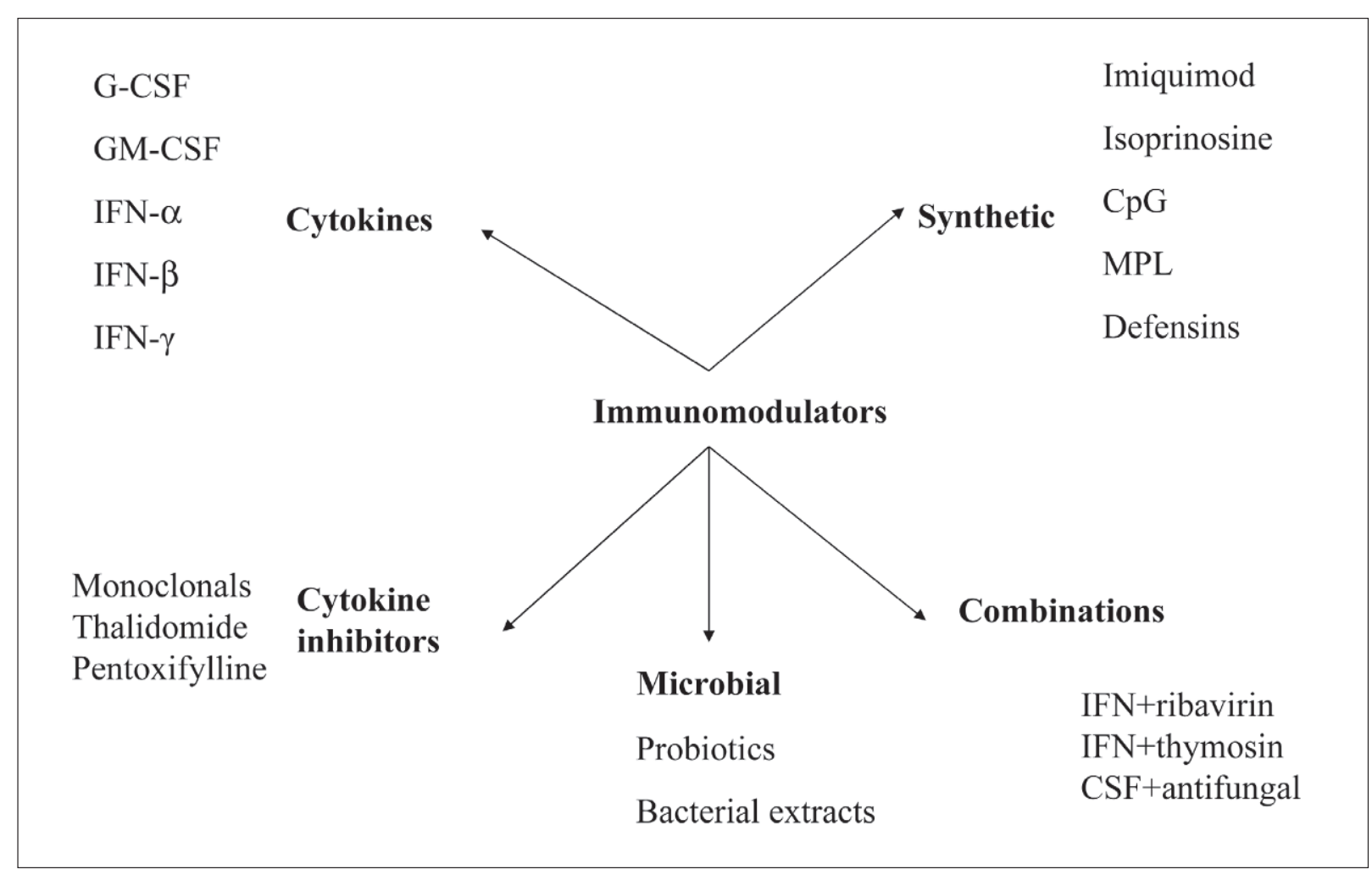

FIGURE 1. BROAD CLASSIFICATION OF IMMUNOMODULATORS 


\section{Cytokine immunomodulators}

The interactions between a host and an infectious pathogen are complex, diverse and intricately regulated. CYTOKINES, hormone-like polypeptides possessing pleiotropic properties, are crucial in orchestrating the appropriate immune responses critical for the outcome of an infection. Certain CYTOKINES stimulate the production of other CYTOKINES and interact in synergistic or antagonistic networks. CYTOKINES exhibit specific immunomodulatory properties that can enable manipulation of the host response to enhance overall immunogenicity, and direct the nature of the response either toward a type 1 or type 2 pathways. In the type 1 response, Th1 cells produce interferon (IFN)- $\gamma$, TUMOR NECROSIS FACTOR (TNF) and INTERLEUKIN (IL)-12 that are required for effective development of cell-mediated immune responses to intracellular microbes. In the type 2 response, Th2 cells produce IL-4, IL-5 and IL-13 that enhance humoral immunity to T-DEPENDENT ANTIGENS and are necessary for immunity to helminth infections.

Recent studies have shown DENDRITIC CELLS (DCs) to be crucial antigen-presenting cells that possess unique $\mathrm{T}$ cell-stimulatory capacity. In mouse, lymphoid progenitor-derived DENDRITIC CELLS (DC1) can express IL-12 and preferentially induce type $1 \mathrm{~T}$ cell responses, whereas myeloid progenitor-derived DENDRITIC CELLS (DC2) express IL-10 and induce type $2 \mathrm{~T}$ cell responses. In humans, DCs are subdivided into plasmacytoid DCs, which secrete copious amounts of IFN- $\alpha$, and myeloid DCs. Both subtypes of DCs recognize diverse microbial pathogens through specific TOLL-LIKE RECEPTORS (TLR). Local and systemic effects of CYTOKINES are, thus, intimately involved in the host control of infections (Fig. 2) (also see chapters A4, A5, A7). Several RECOMBINANT and NATURAL cytokine

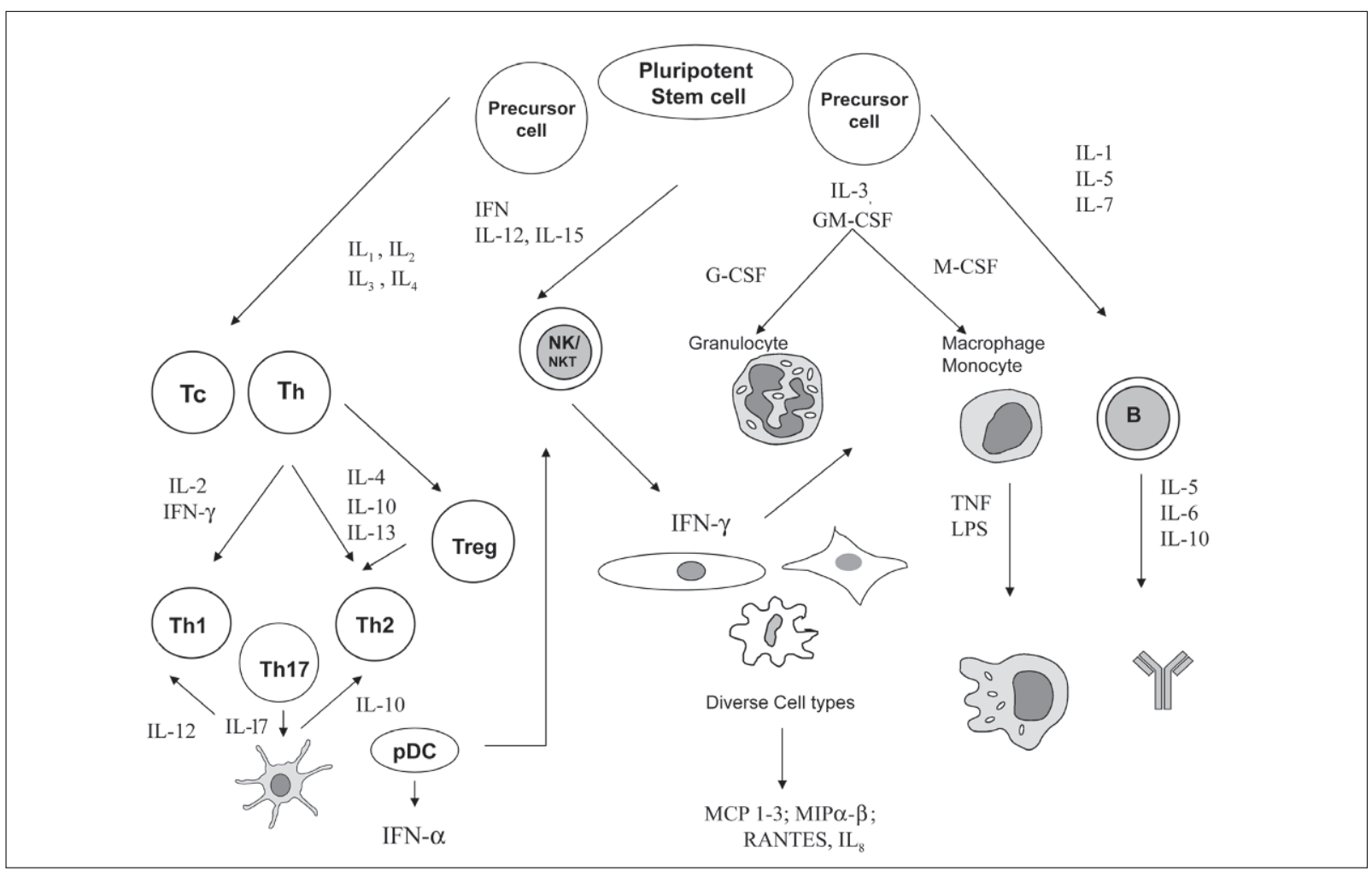

FIGURE 2. INTERACTION OF IMMUNE SYSTEM CELLS AND CYTOKINES 
preparations such as, IFNs, and granulocyte colonystimulating factor (G-CSF) are already licensed for use in patients.

\section{Interferons and combinations}

IFNs play an important role in immune activation and mediate an antiviral state that results in impaired viral replication. There are two classes of IFN, type I and type II.The type I IFN is produced in response to a viral infection and includes IFN- $\alpha$ and IFN- $\beta$. Most of the IFN- $\alpha$ in human is released by the plasmacytoid DCs, whereas IFN- $\beta$ is produced by fibroblasts and many other cell types. IFN- $\alpha$ was the first cytokine to be produced by the RECOMBINANT DNA technology. The type II IFN is secreted by activated T cells and NK cells. IFN- $\gamma$, known as immune interferon, is a representative of type II IFN. Immunomodulatory IFNs also include omega IFN, tau IFN, asialo IFN and consensus IFN. The mode of action of IFN includes reduction of viral gene protein synthesis, APOPTOSIS, and up-regulation of MAJOR HISTOCOMPATIBILITY COMPLEX (MHC) molecules. The immunity-promoting action of IFN may be a result of direct effect on Th1 differentiation, activation of Stat 4 signaling and enhancement of ANTIBODY through stimulation of B and $\mathrm{T}$ cells.

IFN- $\alpha$ is a clinically effective therapy used in a wide range of viral infections besides its application in malignant melanoma, basal cell carcinoma and warts. NATURAL IFN- $\alpha$ obtained from human serum and LEUKOCYTES is currently licensed for the treatment of a rare form of cancer, hairy cell leukemia. RECOMBINANT IFN- $\alpha 2 \mathrm{a}$ is licensed for treatment of chronic active hepatitis B and for HEPATITIS C VIRUS infections.

Standard IFN- $\alpha$ has the drawbacks of a short serum half-life and rapid CLEARANCE. To overcome this problem, PEGYLATED forms of IFN have been developed and tested clinically (Box 1). PegYLATED IFN$\alpha 2 \mathrm{~b}$ (PegIntron) is formed by covalent conjugation of a $12-\mathrm{kDa}$ monomethoxy polyethylene glycol molecule to IFN- $\alpha 2 b$, and PEGYLATED IFN- $\alpha 2 a$ (Pegasys) by covalent conjugation of a $40-\mathrm{kDa}$ branched monomethoxy PEG molecule to IFN- $\alpha 2 a$. PeGYLATED IFN- $\alpha 2 \mathrm{~b}$ has a prolonged serum half-life (40 hours) relative to standard IFN- $\alpha 2 b$ ( $7-9$ hours). The greater polymer size of PEGYLATED IFN- $\alpha 2 a$ acts to reduce glomerular filtration, markedly prolonging its serum half-life (72-96 hours) compared with standard IFN$\alpha 2 \mathrm{a}$ (6-9 hours) [7].

\section{Hepatitis B}

Hepatitis viruses cause INFLAMMATION of the liver. There are five types of hepatitis viruses as is shown in Table 1. Hepatitis A, hepatitis B, and hepatitis $\mathrm{C}$ are the most common types. Hepatitis B VIRUS (HBV) infection is widespread throughout the world, especially in developing nations, and is considered to be a serious global health problem. HBV is HETEROGENEOUS and has eight genotypes, A-H. Genotype D is more prevalent in Mediterranean countries, whereas genotype A is frequent in Western countries. Patients infected with genotype $\mathrm{C}$ have more severe outcome of chronic liver disease than those infected with genotype B, particularly in Asia, who seroconvert earlier than those infected with genotype C. Trans-

\section{Box 1. Pegylated interferons}

Pegylated IFN- $\alpha 2 \mathrm{a}$ is formed by covalent conjugation of a $40-\mathrm{kDa}$ branched monomethoxy PEG molecule to IFN- $\alpha 2 \mathrm{a}$. Pegylated IFN- $\alpha 2 \mathrm{~b}$ is formed by covalent conjugation of a $12-\mathrm{kDa}$ monomethoxy polyethylene glycol molecule to IFN$\alpha 2 b$.

Greater polymer size of pegylated IFN reduces glomerular filtration.

Serum half-life is prolonged from 6-9 hours to 72-96 hours.

Pegylated IFN is injected only once weekly in contrast to multiple administrations necessary for standard IFN, improving patient compliance. 
TABle 1. Hepatitis VIRUSes

\begin{tabular}{|c|c|c|}
\hline Hepatitis virus & Source of infection & Comments \\
\hline Hepatitis A virus & Contaminated food & Most common type, vaccine available \\
\hline Hepatitis B virus, (serum hepatitis) & Blood products, body fluids & $\begin{array}{l}\text { Highly contagious, causes liver cancer, } \\
\text { vaccine available }\end{array}$ \\
\hline Hepatitis C virus & Infected blood, blood transfusion & Chronic liver infection \\
\hline Hepatitis D virus, (delta hepatitis) & Infectious blood & $\begin{array}{l}\text { Incomplete virus, infection only in presence } \\
\text { of hepatitis B, common in Mediterranean } \\
\text { region }\end{array}$ \\
\hline Hepatitis E virus & $\begin{array}{l}\text { Fecal matter, contaminated } \\
\text { water }\end{array}$ & Endemic in South America and India \\
\hline
\end{tabular}

mission is perinatal in areas of high prevalence and sexual or parenteral in regions with low prevalence. The virus, transmitted by blood or body fluids, is up to 100 times more infectious than HUMAN IMMUNODEFICIENCY VIRUS (HIV). HBV infects around 400 million people and kills between 1 and 2.5 million people a year. Overall, $15-25 \%$ of HBV carriers die from chronic hepatitis, cirrhosis or hepatocellular carcinoma (HCC). HCC accounts for up to $90 \%$ of all liver cancers, and individuals who carry HBV have a greater than 100-fold increased relative risk of developing HCC. The development of HBV to HCC is due to the activation of a signaling pathway that includes the protein $\beta$-catenin. Around $50-70 \%$ of all HCC tumors show an abnormal accumulation of this oncoprotein within the cell.

At present, the three licensed therapies widely used for treating liver disease caused by HBV are IFN- $\alpha$ (Box 2), lamivudine and adefovir. A further potent inhibitor of HBV DNA polymerase, entecavir, was approved in 2005 by the US FDA. Lamivudine gets incorporated into growing DNA chains and leads to premature chain termination. Adefovir is an oral adenosine monophosphate (nucleotide) analogue that acts by inhibiting reverse transcriptase and DNA polymerase activity of HBV. Entecavir (Baraclude) is an orally administered cyclopentyl guanosine analogue that is rapidly phosphorylated to the active intracellular 5'-triphosphate form capable of inhibiting replication of HBV at three different steps. Most of these therapies are limited in the clinic by a low response rate in terms of loss of hepatitis Be antigen (HBeAg), NORMALIZATION of serum transaminase levels and loss of HBV DNA. Only a small subset of patients with hepatitis B and around $40 \%$ of cases with hepatitis $\mathrm{C}$ are generally responsive to IFN therapy. IFN- $\alpha$ is also approved for treating conyloma acuminata caused by human papilloma virus and for Kaposi sarcoma in patients with HIV INFECTION.

Long-term treatment with lamivudine or adefovir can result in selection of DRUG-RESISTANT mutants, while troublesome side effects limit the use of IFN$\alpha$. Adefovir has been shown to be effective in suppressing lamivudine-resistant HBV. Several promising studies have shown the effectiveness of adefovir and PEGYLATED IFN- $\alpha 2 \mathrm{a}$ and lamivudine-interferon COMBINATION THERAPY and it is gaining increasing favor in the treatment of chronic HBV [8]. PeGYLATED IFN- $\alpha 2 \mathrm{a}$ plus adefovir or lamivudine has been shown to offer a superior protection $[9,10]$ and to be of a better cost-benefit value. Besides PEGYLATED IFN [11], newer drug formulations demonstrated in clinical trials to be active against HBV include tenofovir, telbivudine and clevudine.

Thymosin- $\alpha 1$ is a SYNTHETIC immunomodulator that mimics thymic-derived thymosin [12] and is approved in over 35 countries for the treatment of viral hepatitis. Thymosin- $\alpha 1$ influences T cell maturation, production of Th1 CYTOKINES, and activity of NK cell-mediated сүтотохІсітY. Thymosin- $\alpha 1$ stimulates 


\section{Box 2. Response to IfN treatMent in PATIENTS With hepatitis B AND C}

Hepatitis B virus has eight genotypes, A-H.

Patients with genotype A, B and C give sustained response to PEG-IFN- $\alpha$ when they have high transaminases or low virus levels.

Genotype D patients are more prevalent in the Mediterranean region and have a lower chance of sustained response to PEG-IFN- $\alpha$.

Hepatitis C virus has six genotypes, $1-6$.

Genotype 1and 4 are resistant to IFN therapy, whereas genotypes 2 and 3 are more responsive.

IFN- $\alpha 2 b$ plus ribavirin combination therapy is effective in chronic hepatitis $\mathrm{C}$ virus patients with genotypes 2 and 3.

Treatment duration is 48 weeks for genotype 1 but only 24 weeks for other genotypes.

maturation of CD34 STEM CELLS into $\mathrm{CD} 3^{+} \mathrm{CD} 4^{+}$cells and induces increased IL-7 synthesis and GM-CSF, IFN- $\alpha$, IFN- $\gamma$ and IL-2 production. Patients with chronic hepatitis B treated with thymosin- $\alpha 1$ had augmented NKT cells and CD8 ${ }^{+}$CYTOTOXIC T LYMPHOCYTES in the liver [13]. Forty-eight weeks after thymosin- $\alpha 1$ treatment some patients showed normalized ALT and decreased HBV-DNA to undetectable level from serum. The lamivudine and thymosin- $\alpha 1$ combination treatment was shown to be superior to lamivudine monotherapy and gave better virological response, HBeAg seroconversion and biochemical response [14]. The combination of thymosin- $\alpha 1$ and IFN- $\alpha$ has been used in patients affected by chronic $\mathrm{B}$ and $\mathrm{C}$ hepatitis including IFN-non-responders [15]. The combination of thymosin- $\alpha 1$, ribavirin and either PEGYLATED IFN- $\alpha,-\alpha 2 \mathrm{a},-\beta$ and $-\gamma$ are stated to simultaneously and substantially reduce or eliminate the side effects normally associated with the administration of IFN alone. A number of studies have shown that genotype $\mathrm{B}$ is associated with a higher response rate to thymosin- $\alpha 1$ therapy than genotype $\mathrm{C}$.

\section{Hepatitis C}

Hepatitis C VIRUs (HCV) is the major ecological agent of post-transfusion and community-acquired non-A, non-B hepatitis worldwide. It is estimated that over 200 million people worldwide are infected by the virus. $\mathrm{HCV}$ infection is a common cause of chronic viral liver disease and is a leading indication for liver transplantation. Almost all such patients show recurrent hepatitis $\mathrm{C}$ viremia. Progressive fibrosis and cirrhosis after liver transplantation have been observed with some of the patients progressing to cirrhosis within 5 years of transplantation. COMBINATION THERAPY with PEGYLATED IFN and ribavirin (Pegetron) is the current standard of care for the treatment of chronic hepatitis $\mathrm{C}$ (CHC) infection. The mechanisms for the observed synergistic effects of combination of PEGYLATED IFN- $\alpha$ and ribavirin have not been elucidated in detail, but in addition to direct antiviral mechanisms, the immunomodulatory effects of both drugs seem to be important, with a shift from Th2 to Th1 cytokine profiles in successfully treated patients. HCV has six genotypes, 1-6, multiple subtypes and quasi-species (Box 2). Genotype 1 is considered to be the most resistant to therapy, whereas genotypes 2 and 3 are more responsive to therapy; genotype 4 seems to be similar to genotype 1 in this respect. IFN- $\alpha 2 b$ plus ribavirin COMBINATION THERAPY has been found to be effective in chronic HCV patients with genotypes 2 and 3 who are virological non-responders to IFN monotherapy $[7,16]$. The treatment duration is 48 weeks for genotype 1 and 24 weeks for other genotypes.

Pegylated IFN- $\alpha 2 a(40 \mathrm{kDa})$ has superior virological EFFICACY to IFN- $\alpha 2 \mathrm{a}$, and elicits histological improvements in chronic hepatitis $\mathrm{C}$ genotype 1 patients, with and without sustained virological response, and is effective in those with liver cirrho- 
sis. The addition of ribavirin to PEGYLATED IFN- $\alpha 2 \mathrm{a}$ (40 kDa) further enhances the therapeutic benefit for patients with hepatitis C [17]. Once-weekly dosing with either PEGYLATED IFN- $\alpha 2 a$ or PEGYLATED IFN$\alpha 2 \mathrm{~b}$ has been shown to produce significantly higher rates of viral eradication than standard thrice-weekly IFN- $\alpha$ therapy. With respect to the treatment of $\mathrm{CHC}$, the greatest anti-HCV EFFICACY has been achieved with the combination of once-weekly PEGYLATED IFN and ribavirin [7]. In a clinical study to assess the sustained loss of serum HCV-RNA 12 weeks post-treatment, a regimen employing ribavirin plus PEGYLATED IFN- $\alpha 2 b$ for 48 weeks gave a successful response in $54 \%$ of patients, with a $41 \%$ response in those with HCV genotype 1.

IFN- $\beta$ obtained from human FS-4 fibroblast cell lines is licensed for use in severe uncontrolled virusmediated diseases in cases of viral encephalitis, herpes zoster and varicella in immunosuppressed patients. A further indication is viral infection of the inner ear with loss of hearing. The standard treatment for MULTIPLE SCLEROSIS, a disease without definitively elucidated etiology, is currently IFN- $\beta$.

IFN- $\gamma$ is the major mediator of host resistance during the acute and chronic phases of infection, and is pivotal in protection against a variety of intracellular pathogens. IFN- $\gamma$ is primarily produced by T cells, NK cells, and NKT cells. IFN- $\gamma$ is produced by both $\mathrm{CD}^{+}$and $\mathrm{CD}^{+} \mathrm{T}$ cells and can induce MHC class I and class II products. The MECHANISMS OF ACTION that distinguish IFN- $\gamma$ from type I IFNs are in stimulation of DCs and MACROPHAGES to upregulate major $\mathrm{MHC}$ molecules to enhance antigen presentation and increase expression of COSTIMULATORY MOLECULES. IFN- $\gamma$-stimulated MACROPHAGES can produce reactive nitrogen intermediates. NK cells secrete IFN- $\gamma$ early on during an infection and so facilitate immune cell recruitment and activation, enhancing NK cell CYTOTOXICITY and cell mediated immune responses. Additionally, IFN- $\gamma$ recruits NEUTROPHILS, and up-regulates CHEMOKINES and ADHESION MOLECULES, and triggers rapid superoxide production and RESPIRATORY BURST. Patients with chronic granulomatous disease are unable to generate an OXidative RESPIRATORY BURST. As a consequence, they develop recurring catalase-positive bacterial infections such as $S$. aureus, Pseudomonas cepacia, and
Chromobacterium violaceum. Multicenter clinical trials have shown that sustained administration of IFN- $\gamma$ to chronic granulomatous disease patients markedly reduced the relative risk of serious infection. IFN- $\gamma$ is licensed as a therapeutic adjunct for use in patients with chronic (septic) granulomatosis for reduction of the frequency of serious infections. Imukin and Actimmune $^{\mathrm{TM}}$ are IFN- $\gamma$ preparations marketed for chronic granulomatous disease, mycobacterial and fungal infections.

The major side effects of all interferon therapies include flu-like syndromes, fever, myalgia, headache and fatigue. Hypotension, granulocytopenia, and thrombocytopenia can also occur. Deleterious effects on CENTRAL NERVOUS SYSTEM (CNS), particularly at high doses, have been observed.

\section{Colony-stimulating factors}

Granulocyte colony-stimulating factor (G-CSF) preparations such as Filgrastim (r-metHuG-CSF) can significantly enhance neutrophil functions. Filgrastim induces neutrophil production within the BONE MARROW by stimulating the proliferation, differentiation and survival of myeloid progenitor cells. A high incidence of NEUTROPENIA is seen in HIV-infected patients, which considerably increases the risk for bacterial and fungal infections. G-CSF preparations such as Filgrastim can significantly enhance neutrophil functions in patients with AIDS [18] and reverse NEUTROPENIA associated with HIV and cytomegalovirus (CMV) infections. Filgrastim has been granted license extension to cover the treatment of persistent NEUTROPENIA at an advanced stage of HIV INFECTION. In one study, Filgrastim-treated patients have been shown to have $54 \%$ fewer severe bacterial infections and $45 \%$ fewer days in hospital for any bacterial infections [19]. Determination of absolute numbers of CD $34^{+}$progenitor cells and progenitor cell function in HIV-infected patients showed that G-CSF mainly increases the number and differentiation of myeloid progenitors. In another study conducted at 27 European centers on AIDS patients with CMV infection, G-CSF (LENOGRASTIM) was found to be suitable for the treatment of ganciclovir-induced NEUTROPENIA [20]. Recently, pegfilgrastim, a novel RECOMBINANT human 
G-CSF, has been pharmaceutically developed by covalent binding of a polyethylene glycol molecule to the N-terminal sequence of FILGRASTIM.

G-CSF and granulocyte-macrophage colonystimulating factor (GM-CSF) are used to reverse leukopenia as adjunctive therapy for HIV-associated infections. The GM-CSF preparation Sargramostim helps overcome defects in neutrophil and macrophage function due to its broad range of effects On LYMPHOCYTES, MACROPHAGES, NEUTROPHILS, and DCS through augmentation of cytokine secretion and upregulation of MHC class II and accessory RECEPTORS involved in the immune response. It enhances the anti-retroviral activity of zidovudine and stavudine in MACROPHAGES and ameliorates the hematological side effects of these agents. Multiple deficiencies are involved in the progression of fungal infections in cancer patients with or without NEUTROPENIA. Although clinical experience is still limited, G-CSF, GM-CSF, and M-CSF show promise as adjuvant therapy for fungal infections [21].

\section{Chemokines and chemokine modulators}

Chemokines have been historically regarded as leukocyte chemoattractants capable of regulating cellular trafficking into inflammatory sites. The sobriquet 'chemokine' is abbreviated from chemotactic CYTOKINES. Accumulating evidence suggests that CHEMOKINES have a broad range of functions including macrophage activation, neutrophil DEGRANULATION, DC maturation, $T$ cell activation and B cell ANTIBODY CLASS SWITCHING. ThUS, CHEMOKINES can influence both the innate and acquired phases of an immune response. Chemokines can be mediators of angiogenesis and also play important roles in the development of the immune, circulatory and CNS. The major classes of CHEMOKINES comprise the CXC or $\alpha$ CHEMOKINES, the CC Or $\beta$ CHEMOKINES, the $\mathrm{C}$ or $\gamma$ CHEMOKINES, and the CX3C CHEMOKINES. The chemokine family has expanded to 80 ligands including CXCL, CCL, XCL and CX3CL CHEMOKINES and chemokine RECEPTORS including CXCR, CCR, XCR and CX3CR have been described in Table 2.

Many erudite reviews on HIV/AIDS etiology and manifestation have been published and these are not be dealt with here (see the recommended thebody. com website). It is noteworthy that currently there are more women worldwide who have been infected with HIV and account for nearly half of the over 40 million people living with HIV [22]. Women are more vulnerable to HIV INFECTION than men and their increased susceptibility has been linked to the use of hormonal contraceptives and sexually transmitted diseases. Also, susceptibility to HIV varies throughout a women's reproductive life; adolescent girls appear to be most vulnerable to HIV due to high-risk sexual behavior and a not fully mature reproductive system. In addition, recent studies have indicated increases in the risk of acquiring HIV during pregnancy and during the early postpartum period, part of which could be attributed to higher levels of progesterone. Successful control of the HIV pandemic requires continuing focus on gender. Some of the fundamental issues of HIV transmission have been riddled with problems as it is neither feasible to obtain nor examine relevant cells and tissue at the PRECISE time of HIV acquisition.

HIV can infect a wide range of human cells, but has a particular tropism for $\mathrm{CD}^{+} \mathrm{T}$ cells and the monocyte-macrophage cell lineage [23]. HIV induces $\mathrm{T}$ cell dysfunction and $\mathrm{CD}^{+} \mathrm{T}$ cell APOPTOSIS, decreasing the number of $\mathrm{T}$ cells, which ultimately leads to immunodeficiency. B cell dysfunction can be caused by HIV and is characterized by hypergammaglobulinemia, polyclonal activation, and absence of specific ANTIBODY responses. HIV entry into the host cell is mediated through the CD4 RECEPTOR and a variety of coreceptors. Chemokine RECEPTORS - mainly CCR5 and CXCR4 - have been discovered to be necessary as coreceptors for HIV entry [24].

The binding of the HIV envelope glycoprotein gp120 to CD4 and appropriate chemokine RECEPTOR triggers conformational changes facilitating the fusion of the viral and host cell membranes. HIV found in the vaginal and rectal mucosa is mainly CCR5 dependent [25]. Macrophage-tropic (R5) HIV variants predominantly make use of the CCR5 coreceptors [26]. The T cell-tropic (X4) and dualtropic (R5X4) HIV strains, generally associated with the clinical manifestations of AIDS, emerge after a latency of several years, although pathogenesis of the 
TABLE 2. Chemokine ReCEPTORS AND LIGANDS

\begin{tabular}{|c|c|c|}
\hline Chemokine receptors & Ligands & Some original names \\
\hline \multicolumn{3}{|l|}{ CC family } \\
\hline CCR1 & CCL3, 3L1, 5, 7, 14, 15, 16, 23 & MIP-1 $\alpha$, MCP-3, HCC-2, HCC-4 \\
\hline CCR2 & $\mathrm{CCL} 2,7,12,13,16$ & MCР-1, МСР-3, МСР-2, МСР-5, МСР-4 \\
\hline CCR 3 & $\mathrm{CCL} 5,7,8,11,13,24,26,28$ & RANTES, MCP-3, MCP-2, Eotaxin \\
\hline CCR4 & CCL17, 22 & TARC, MDC \\
\hline CCR5 & CCL3, 3L1, 4, 5, 8, 14 & MIP- $1 \alpha$, MIP- $1 \beta$, RANTES \\
\hline CCR6 & CCL20 & MIP-3 $\alpha$ \\
\hline CCR7 & CCL19, 21 & MIP-3ß, SLC \\
\hline CCR8 & CCL1, 16, 17 & TCA3, HCC-4, TARC \\
\hline CCR9 & CCL25 & TECK \\
\hline CCR10 & CCL27, 28 & CTACK ,CCL28 \\
\hline \multicolumn{3}{|l|}{ CXC family } \\
\hline CXCR1 & CXCL6, 8 & GRO- $\alpha$, NAP-2, IL-8, \\
\hline CXCR2 & CXCL1, 2, 3, 5, 6, 7, 8 & GRO- $\alpha$, GRO- $\beta$, GRO- $\gamma$, IL-8 \\
\hline CXCR3 & CXCL9, 10, 11 & MIG, IP-10, I-TAC \\
\hline CXCR4 & CXCL12 & SDF-1 \\
\hline CXCR5 & CXCL13 & BLC \\
\hline CXCR6 & CXCL16 & CXCL16 \\
\hline
\end{tabular}

CNS and related symptoms are normally associated with M-tropic (R5) HIV strains. X4 HIV INFECTION augments the expression of CHEMOKINES such as MIP-1 $\alpha$ (macrophage inflammatory protein) and RANTES (regulated upon activation normal T cell expressed and secreted) [27].

HIV INFECTION can be inhibited by CHEMOKINES and chemokine-related molecules that are ligands for RECEPTORS that function as CORECEPTORS [28]. Chemokine RECEPTORS thus represent important tar- gets for intervention in HIV, and the search for molecules that have a therapeutic potential as inhibitors of these RECEPTORS has been intense [29]. Intervention strategies based on chemokine antagonists that could be useful for the therapy of HIV include RECEPTOR-LIGAND interaction, prevention of the chemokineglycosaminoglycan interaction, interfering with the signaling pathways that are induced upon RECEPTOR activation, and modification of RECEPTOR pathways $[30,31]$. 


\section{Targeting CCR5 and CXCR4}

The chemokine RECEPTORS CXCR4 and CCR5 are the main CORECEPTORS used respectively by the $T$ celltropic (CXCR4-using, X4) and macrophage-tropic (CCR5-using, R5) HIV for cell entry. Several compounds targeting CXCR4 and CCR5 have been advocated recently. The idea for the drug class came from the observation that presence of mutated CCR5 can confer resistance to HIV INFECTION, even after exposure to numerous high-risk sexual partners. Only around $2 \%$ of Caucasians carry such a mutation.

Modified CHEMOKINES, e.g., several low-molecular weight CXCR4 and CCR5 antagonistic compounds, with potent antiviral activity have been described. Maraviroc developed by Pfizer is the first-in-class CCR5 antagonist. It was licensed in October 2007 by the FDA for use in HIV treatment-experienced patients harboring only R5 viruses. It has been shown to prevent the binding of endogenous chemokine MIP-1 $\beta$ to the CCR5 RECEPTOR. The mechanism of action of maraviroc is one of allosteric modification within the transmembrane helices to disrupt the interaction between CCR5 and HIV-1 gp120.

Bicyclam AMD3100 targets CXCR4 and has a potent anti-HIV activity against T-tropic viruses. AMD3100 is being tested in phase III clinical trials as a stem cell recruiting agent in transplantation patients with non-Hodgkin's lymphoma or multiple myeloma. A derivative AMD3451, pyridinylmethyl monocyclam, has been synthesized and reported to show dual CCR5/CXCR4 antagonistic activity against both X4 and R5 HIV strains [32]. In a pharmacokinetics and safety study of AMD3100 in 12 healthy human volunteers, subjects tolerated their dose(s) well without any grade 2 toxicity or dose adjustment. Six subjects experienced mild, transient symptoms, primarily gastrointestinal in nature and not dose related. All subjects experienced a dose-related elevation of the white blood cell count, from 1.5 to 3.1 times the baseline, which returned to the baseline $24 \mathrm{~h}$ after dosing [33]. AMD3100 has been shown to interfere with a number of physiological processes that are dependent on the interaction of CXCR4 with SDF-1 [34]. Another chemokine (CCR5) inhibitor, aplaviroc or GSK 873140, has been selected recently by GlaxoSmithKline for phase III trials. Other compa- nies working on CCR5 antagonists include Pfizer Inc and Schering-Plough Corp.

Most existing HIV drugs work inside the body's immune cells, after the virus has infected, and can cause anemia, diarrhea and nerve pain. These new drugs could provide an important treatment option for people with HIV/AIDS, by offering a different mode of action and an improved toxicity profile. Both CXCR4 and CCR5 chemokine RECEPTOR inhibitors may be needed in combination and even in combinations of antiviral drugs that also TARGET other aspects of the HIV replication cycle to obtain optimum antiviral therapeutic effects.

\section{RANTES and MIP ligands}

Primary isolates of HIV predominantly use chemokine RECEPTOR CCR5 to enter TARGET cells. The NATURAL ligands of CCR5, the $\beta$-CHEMOKINES, RANTES, MIP- $1 \alpha$, and MIP-1 $\beta$, interfere with HIV binding to CCR5 RECEPTORS and decrease the amount of virions entering cells. Productive HIV INFECTION of primary LYMPHOCYTES requires cellular activation, which increases the intracellular cAMP required for efficient synthesis of proviral DNA during early steps of viral infection. Binding of $\beta$-CHEMOKINES to cognate RECEPTORS decreases activation-induced intracellular cAMP levels through the activation of inhibitory $\mathrm{G}$ proteins. RANTES and similar CHEMOKINES have been shown to exhibit clear-cut suppressive effects on HIV replication, and other CHEMOKINES such as MIP$1 \alpha$ and monocyte chemotactic protein (MCP) frequently show HIV-inhibitory effects [35]. MIP-1 $\alpha$ and RANTES can also reduce T LYMPHOCYTE APOPTOSIS in HIV-infected individuals.

A number of experimental approaches directed towards RANTES have been explored. CCR5 can be down-modulated by RANTES and by ANTIBODIES to CCR5 [25]. It is desirable that CHEMOKINES block HIV INFECTION without triggering CCR3- or CCR5-signaling activity. Two analogues showing increased anti-HIV potency (L-RANTES and C1.C5-RANTES) but capable of antagonistic action against RANTES have been synthesized [29]. The N-terminal region of RANTES contains critical determinants not only for the triggering of RECEPTOR-mediated signaling, but also for 
the antiviral function. RECOMBINANT RANTES analogues mutated at the $\mathrm{N}$ terminus (C1.C5-RANTES and L-RANTES) and a modified form of RANTES, aminooxypentane (AOP)-RANTES have been synthesized that exhibit an increased binding AFFINITY for CCR5, while showing antiviral activity against different CXCR4-negative HIV [36] and mixed infections with clinical HIV isolates [37]. Promising EFFICACY as a HIV- microbicidal candidate for TOPICAL application has been shown by N-terminally modified chemokine PSC-RANTES against R5-tropic HIV-1 strains. PSC-RANTES is fully protective when applied topically in a macaque model [38], and when encapsulated into biodegradable co-polymer poly(lacticco-glycolic acid) (PLGA) nanoparticles [39]). Other analogues such as 5P12-RANTES and 6P4-RANTES have been synthesized [40] and shown to protect against rhesus HIV vaginal challenge.

\section{Cytokine inhibitors}

Several strategies exist for responding to infection. One mechanism by which the host attempts to restrain the infection is through the up-regulation of CYTOKINES. SOMe CYTOKINES, such as IL-1, IL-6, IL-8, IL-18, and TNF, counteract the challenge by enhancing the disease in an effort to rid the host of infection. Overproduction of proinflammatory CYTOKINES is believed to underlie the progression of many inflammatory diseases including RHEUMATOID ARTHRITIS, Crohn's disease and ENDOTOXIN SHOCK. Many infectious diseases, including $\mathrm{HIV}$, influenza $\mathrm{H} 5 \mathrm{~N} 1$ and malaria can induce deleterious overproduction of proinflammatory CYTOKINES such as TNF- $\alpha$ and IL- 1 . An attractive therapeutic approach for potential drug intervention in these conditions is the strategic reduction of proinflammatory CYTOKINES

Intense interest has been generated in developing agents that can block the activity of such CYTOKINES. Inhibition of TNF activity has been singularly successful in the treatment of AUTOIMMUNE DISEASES (see chapter C15). MONOCLONAL ANTIBODIES including ADALIMUMAB (Humira; Abbott), a fully human monoclonal ANTIBODY, ETANERCEPT (Enbrel; Amgen/Wyeth), a dimeric construct of soluble p75 TNF RECEPTOR and $\mathrm{FC}$ region of human IgG1, INFLIXIMAB (Remicade;
Centocor), a CHIMERIC monoclonal ANTIBODY, and Certolizumab pegol, HUMANIZED anti-TNF Fab' ANTIBODY fragment coupled to polyethylene glycol, are being used in the treatment of RHEUMATOID ARTHRITIS. An IL-1 RECEPTOR antagonist, Kineret, has also been licensed. Some of these monoclonal ANTIBODY products have shown promise for applications in disease management in patients with HIV/AIDS [41].

Another potent TNF inhibitor, thalidomide, has been used in trials in HIV patients [42, 43]. Thalidomide has a chiral center, and the racemate of (R)- and (S)-thalidomide was introduced as a sedative drug in the late 1950s (Fig. 3). It was withdrawn in 1961due to teratogenicity (creating malformation in embryos, from the Greek for "monster") having caused serious birth defects and neuropathy in more than 10000 babies.

Several MECHANISMS OF ACTION have been proposed for thalidomide: as angiogenesis inhibitor, down-regulator of integrin, and agent that can reverse the stimulation of insulin-like growth factor I (IGF-I) and fibroblast growth factor 2 (FGF-2) in early limb development. Structural analogues of thalidomide with improved TNF- $\alpha$ inhibitory activity are currently being developed. Pentoxifylline, a methylxanthine usually used in the treatment of peripheral arterial circulatory disorders, has been shown to inhibit TNF synthesis. Currently, clinical trials are ongoing with phosphodiesterase inhibitors and small-molecule inhibitors of TNF-converting enzyme (TACE) that specifically interrupt the signaling pathways of TNF.

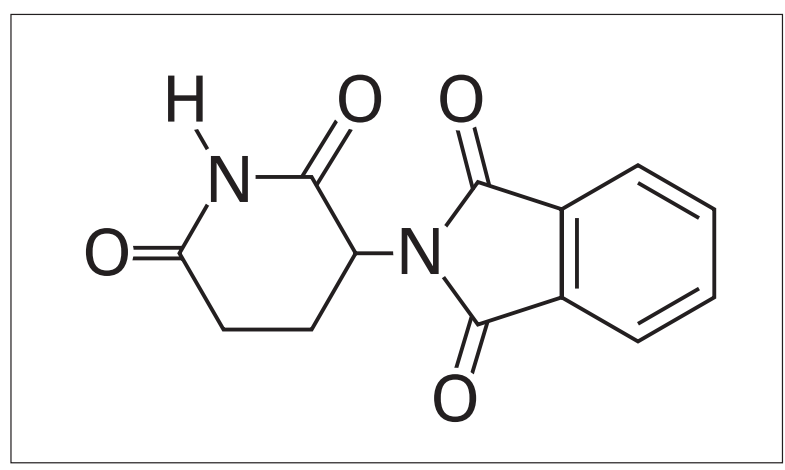

Figure 3. Structure of thalidomide 
TNF plays an important role in defense against bacterial and viral infections. Consequently, many patients on anti-TNF drug therapy have shown severe infections such as tuberculosis [44, 45]. A variety of other opportunistic fungal infections by Candidia,Aspergillus Pneumocystis, Coccidioides, and Histoplasma, have also been reported in patients treated with anti-TNF monoclonals [46].

Sepsis is one of the most common complications in surgical patients and one of the leading causes of mortality in intensive care units. Sepsis can be caused by infection with Gram-negative bacteria, Gram-POSITIVE BACTERIA, fungi, or viruses. Sepsis may, however, also occur in the absence of detectable bacterial invasion. In such cases, microbial toxins, particularly Gram-negative bacterial ENDOTOXIN, and endogenous cytokine release have been implicated as initiators and mediators. Septic SHOCK represents the most severe form of host response to infection. Despite recent progress in antibiotics and critical care therapy, sepsis is still associated with a high mortality rate $(\sim 40-50 \%)$. A number of therapies delaying the onset, and/or reducing the effects of proinflammatory CYTOKINES induced during sepsis are under development [47]. TAK-242 is a small molecule antagonist that reduces LIPOPOLYSACCHARIDE (LPS)-induced production of proinflammatory IL-1, IL-6 and TNF, and is currently undergoing phase III evaluation. Another compound, E5564, or eritoran, is a SYNTHETIC lipodisaccharide and was observed to reduce TNF and IL-6 levels after LPS administration [48] (Fig. 4). Eritoran is being evaluated in a phase III study in patients with onset of severe sepsis. Longterm antagonistic activity can be obtained when eritoran associates with LDL, triglyceride-rich lipoproteins and albumin.

\section{Synthetic immunomodulators}

Microbial pathogens possess a variety of evolutionarily conserved structural motifs known as PATHOGEN-ASSOCIATED MOLECULAR PATTERNS (PAMPS). The PAMPS are recognized by a family of specific TOLLLIKE RECEPTORS (TLRs) that are present on the cells of the IMMUNE SYSTEM such as DCS and MACROPHAGES and play a crucial role in innate immune responses (Tab. 3). Around 13 TLRs exhibiting distinct LIGAND specificities have been identified in humans. TLR2 recognizes bacterial PEPTIDOGLYCAN and lipopeptide, TLR3 recognizes double-stranded RNA, TLR4 binds to LPS,TLR5 binds to flagellin, which is part of the flagellum that propels many kinds of bacteria.TLR7 and TLR8 recognize imidazoquinoline compounds and single-stranded (ss) RNA from viruses, whereas TLR9 binds to unmethylated CpG DNA motifs frequently found in the genome of bacteria and viruses, but not vertebrates. The extracellular portions of microbes are recognized by TLRs, whereas the intracellular

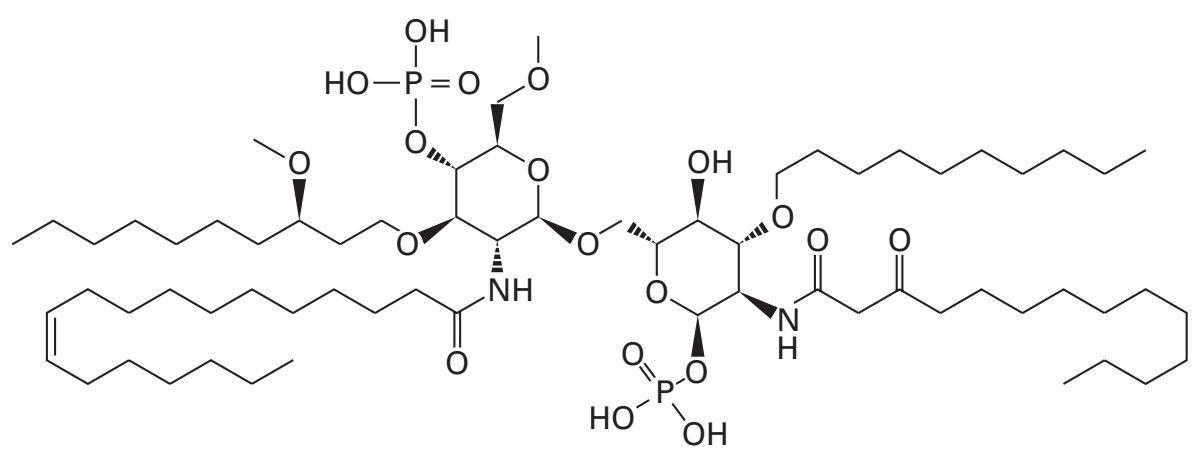

Figure 4. Structure of eritoran 
TABLE 3. TOLL-LIKE RECEPTORS

\begin{tabular}{lll}
\hline TLR & Ligand & Relevant microbial or synthetic source \\
\hline TLR1 & Peptidoglycan, lipopeptide & Gram-positive bacteria \\
TLR2 & Lipoprotein, lipoteichoic acid & Measles virus hemagglutinin protein, RSV \\
TLR3 & dsRNA & CMV, West Nile virus \\
TLR4 & Lipopolysaccharide, lipoteichoic acid, & Gram-negative bacteria, RSV \\
& RSV fusion protein & \\
TLR5 & Flagellin & Flagellated bacteria \\
TLR6 & Lipoprotein & Bacteria \\
TLR7 & Imiquimod, dsRNA & Synthetic compounds, Influenza virus, HIV \\
TLR8 & Imiquimod, thiazoloquinolones, ssRNA & Synthetic compounds \\
TLR9 & Unmethylated CpG & Bacteria, synthetic ODN \\
TLR10 & $?$ & \\
TLR11 & Profilin & Toxoplasma gondii, uropathogenic bacteria \\
TLR12 & $?$ & \\
TLR13 & $?$ & \\
\hline
\end{tabular}

microbial components are sensed by Nod-like RECEPTORS (NLRs) and RIG-I-like RECEPTORS (RLRs).

In humans, TLR7 and TLR9 are expressed on the plasmacytoid DC, which can rapidly synthesize large amounts IFN- $\alpha$ and IFN- $\beta$ in response to viral infection.These observations indicate that TLR3,TLR7 and TLR9 may play an important role in combating viral infections. Interestingly, TLR7 recognizes SYNTHETIC immunomodulators such as imidazoquinolone compounds that are used against viral infections.

\section{Imiquimod derivatives}

IMIQUIMOD is a fully SYNTHETIC immune response enhancing imidazoquinoline amine, (S-26308, R-837) \{1-(2-methylpropyl)-1H-imidazo[4,5-c] quinolin-4 amine [49] and is a TLR7 agonist. IMIQUIMOD is marketed as Aldara ${ }^{\mathrm{TM}}$ for genital warts caused by human papillomavirus (HPV) subtypes 6 and 11, but is widely used for basal cell carcinoma, actinic keratosis and molluscum contagiosum. It has shown promise in lentigo maligna and cutaneous metastases of malignant melanoma. IMIQUIMOD and its derivatives such as resimiquimod (R-848) improve antigen presentation by DCs and also act on B cells leading to the synthesis of ANTIBODIES such as IgG2a (Fig. 5).

These agents activate MACROPHAGES and other cells via binding to cell surface RECEPTORS, such as TLR7, inducing secretion of proinflammatory CYTOKINES, e.g., IFN- $\alpha$, TNF- $\alpha$ and IL-12. The presence of this cytokine milieu biases towards a Th1-type immune response and has been exploited clinically in the treatment of viral infections (HPV, herpes simplex virus, molluscum contagiosum). In randomized, double-blind, placebo-controlled studies, IMIQUIMOD cream has been shown to be significantly effective in eliminating genital warts in patients with clinical, histopathological and polymerase chain reaction confirmed diagnosis of HPV infection and in treatment of external genital and perianal warts. Topically applied IMIQUIMOD cream reduced wart area in HIVinfected patients. 
Imiquimod

(Aldara, R-837, S-26308)<smiles>CC(C)Cn1cnc2c(N)nc3ccccc3c21</smiles>

Resiquimod

(R-848, S-28463)<smiles>CCOCc1nc2c(N)nc3ccccc3c2n1CC(C)(C)O</smiles>

FigURE 5. StRUCTURES OF IMIQUIMOD AND RESIQUIMOD

\section{Isoprinosine}

ISOPRINOSINE (Inosiplex) is a complex of the $p$-acetamidobenzoate salt of $N, N$-dimethylamino-2-propanol: inosine in a 3:1 molar ratio (Fig. 6).

It is a white crystalline powder soluble in water. The inosine portion of ISOPRINOSINE is metabolically labile and half-life in rhesus monkeys has been found to be 3 minutes after intravenous and 50 minutes after oral administration. ISOPRINOSINE has been shown to augment production of CYTOKINES such as IL-1, IL-2 and IFN- $\gamma$, inducing a Th1 bias. It increases proliferation of LYMPHOCYTES in response to mitogenic or antigenic stimuli, increases active T cell rosettes and induces $\mathrm{T}$ cell surface markers on prothymocytes. ISOPRINOSINE is currently licensed in Europe for treatment of herpes simplex infections, subacute sclerosing panencephalitis, acute viral encephalitis caused by herpes simplex, Epstein-Barr and measles viruses and for treatment of these viral infections in immunosuppressed patients. ISOPRINOSINE has been reported to have minor CNS depressant but no neuromuscular, sedative, or antipyretic activities in pharmacological studies in animals. In humans, IsOPRINOSINE may cause transient nausea and a rise in uric acid in serum and urine at high doses.

\section{Emerging therapies with synthetic immunomodulators}

\section{CpG oligodeoxynucleotides}

Over the last decade, nucleotide sequences containing non-methylated cytosine phosphate-guanosine<smiles>CC(O)CN(C)CC(C)O</smiles> 
(CpG) dinucleotides, with flanking regions of two 5' purines and two 3' pyrimidines, have been discovered to play an important role in INNATE IMMUNITY (Fig. 7).

The $\mathrm{CpG}$ motifs in bacterial or viral DNA are detected by TLR9 principally by recognizing differences in the chemical structure between microbial and host DNA. In humans, TLR9 is expressed predominantly in B cells and plasmacytoid DCs.

Although DNA containing CpG motifs (CpG DNA) evolved as a defense system in eukaryotes to probably protect against infection, it is possible to use CpG DNA as an immunomodulator for therapeutic applications. CpG DNA triggers a predominantly Th1 pattern of immune activation and is of interest for the induction of antimicrobial effects. CpG DNA triggers humoral B cell responses and also activates MONOCYTES and MACROPHAGES to secrete CYTOKINES, especially IL-12,TNF, and IFN. Of particular interest is the capability of CpG DNA to overcome the Th2 bias associated with some diseases and in very young and elderly mice $[50,51]$. The exact mechanisms by which CpG DNA induces DCs, MACROPHAGES and NK cells to produce immunomodulating CYTOKINES are being elucidated.

The finding that SYNTHETIC oligodeoxynucleotides (ODNs) can mimic the action of bacterial DNA has galvanized research in this area. Also, several viruses such as influenza A virus, HSV, CMV, respiratory

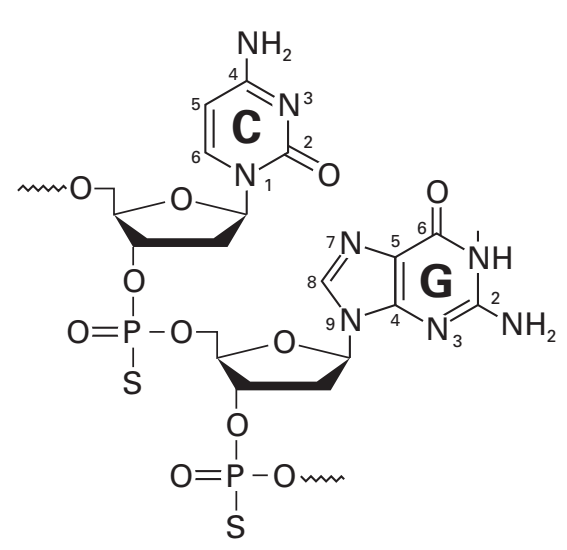

Figure 7. General structure of a CpG-motif syncytial virus (RSV) and vesicular stomatitis virus have been shown to activate cells via TLR family members. Administration of SYNTHETIC ODNs containing $\mathrm{CpG}$ motifs has been shown to confer protection or act as an adjuvant in experimental infections by influenza virus, hepatitis virus, Listeria monocytogenes, Francisella tularensis, Trypanosoma cruzi, and Leishmania, and markedly increases resistance against acute poly-microbial sepsis $[52,53]$. Several human clinical trials have shown that CpG-DNA has low toxicity and is well tolerated $[52,54]$.

\section{Antimicrobial peptides}

ANTIMICROBIAL PEPTIDES (AMPs) also known as host defense peptides (HDPs), are present mainly in phagocytic cells of the IMMUNE SYSTEM and can kill a wide array of Gram-positive and Gram-negative bacteria, enveloped viruses, fungi and parasites through disruption of microbial membranes. The positive charge of AMPs facilitates the interaction with negatively charged surface components, such as LPS in Gram-negative bacterial outer membranes, lipoteichoic acids of GRAM-POSITIVE BACTERIA and heparin sulfate found in viral envelopes [55]. In addition to antimicrobial activity, AMPs also exert immunomodulatory effects through a variety of mechanisms such as CHEMOTAXIS, activation of immature DCs, angiogenesis, and cytokine production [56]. AMPs are genetically encoded and form an important part of the innate immune response (see also chapter A6).

The AMPs are amphipathic cationic molecules of between 10 and 50 amino acids that can be classified into three main groups; $\alpha$-helical peptides (e.g., cathelicidins), $\beta$-sheet peptides (e.g., DEFENSINS); and amino acid-enriched structures (e.g., indolicidin). The structural and functional diversity of AMPs have made them interesting candidates for antiinfective therapy since they have the capability to resolve infections by antibiotic-resistant bacteria [57]. Moreover, they can stimulate innate host defense mechanisms without excessive proinflammatory responses that can be potentially harmful. Two AMPs have been shown to be effective in phase III clinical trials. The $\alpha$-helical magainin analog, pexiganan, has been developed for TOPICAL treatment of 
patients with mild diabetic foot infection and can cure approximately $90 \%$ of the patients. The other AMP,omiganan pentahydrochloride (omiganan) is a nOvel, SYNTHETIC, antimicrobial peptide comprised of 12 amino acid residues with the following primary sequence: ILRWPWWPWRRK- $\mathrm{NH}_{2}$ (where I is isoleucine, $\mathrm{L}$ leucine, $\mathrm{K}$ lysine, $\mathrm{P}$ proline, $\mathrm{R}$ arginine and $\mathrm{W}$ tryptophan). Omiganan, is an indolicidin with EFFICACY in preventing catheter-related infections.

SYNTHETIC peptides that retain many of the immunomodulatory properties of naturally occurring HDPs are currently being explored for their therapeutic potential [58, 59]. Innate defense regulator-1 (IDR-1) is an anti-infective SYNTHETIC peptide that selectively modulates the innate immune response. IDR-1 is a 13-amino acid peptide (KSRIVPAIPVSLL- $\mathrm{NH}_{2}$ ) synthesized by solid-phase synthesis using standard fluorenylmethoxycarbonyl (FMOC) chemistry protocols. MiCROARRAY analysis showed that several transcription factors, including STAT1 and several zinc finger and Hox transcription factors, and ADHESION MOLECULES such as ICAM, NCAM and integrin- $\alpha$ are stimulated by IDR-1. Furthermore, kinase MEK6 (part of the p38 MITOGEN-activated protein kinase pathway) and monocyte-chemotactic-protein (MCP), CHEMOKINES MCP-3 and MCP-1, and CYTOKINES IL-10 and IL-19 are up-regulated. IDR-1 confers protection against multiple bacterial pathogens including strains of methicillin-resistant $S$. aureus and vancomycin-resistant Enterococcus in murine models. IDR-1 has been shown to stimulate monocyte CHEMOKINES, activating monocyte-macrophage cells, and down-regulating proinflammatory cytokine responses without inducing toxic side effects [60].

\section{Defensins}

DEFENSINS are a family of structurally related cysteinerich cationic polypeptides of the INNATE IMMUNE SYSTEM produced in response to microbial infection in humans, animals, insects and plants [61]. Six human $\alpha$-DEFENSINS have been described; HD1, 2,3 , and 4 are secreted primarily by GRANULOCYTES and certain LYMPHOCYTES, whereas HD5 and 6 are expressed by intestinal Paneth cells. The $\beta$-DEFENSINS are produced in response to microbial infection of mucosal tissue and skin (Tab.4).Unusual circular mini-DEFENSINs have also been identified in rhesus monkeys. DeFENSINS of vertebrate animals have been reviewed elsewhere [62]. The mode of action of DEFENSINS includes destabilization and disruption of TARGET cell membranes by strong membrane permeabilizing activities. Permeabilization results in the cessation of RNA, DNA and protein synthesis and with a decreased microbial viability. The human neutrophil DEFENSINS HNP1 and HNP2 exert significant chemotactic effects on MONOCYTES. $\beta$-DEFENSINS are chemoattractive for memory T cells and immature DCs and lead to expression of proinflammatory CHEMOKINES and CYTOKINES such as RANTES, macrophage-derived chemokine (MDC), interferon- $\gamma$ inducible protein 10 (IP-10), MIP-1 $\alpha$ and MIP-1 $\beta$, TNF- $\alpha$, IL-1 and IL-12.

Recent reports have highlighted the anti-HIV activities of DEFENSINS, whose structure and charge resemble portions of the HIV-1 transmembrane envelope glycoprotein gp41. CD8 T LYMPHOCYTES from certain immunologically stable HIV-infected individuals secrete soluble factors that suppress HIV replication. CD8 T cells from long-term non-progressors with HIV INFECTION were found to secrete a cluster of proteins identified as $\alpha$-defensin 1,2, and 3 on the basis of specific ANTIBODY recognition and amino acid sequencing. Interestingly, $\alpha$-DEFENSINS were shown to effectively suppress HIV replication in vitro about 10 years ago and can specifically block the initial phase of the HIV infectious cycle by binding specifically to CD4, and gp120 [63].A study of seronegative women who were exposed constantly to HIV-1 demonstrated that their $\mathrm{CD}^{+}$cells exhibit extensive $\alpha$-defensin production at both peripheral and mucosal levels. The $\alpha$-defensin expression level in these seronegative women was tenfold higher than that of control subjects [64]. Likewise, overexpression of $\alpha$-DEFENSINS in breast milk results in a low rate of HIV-1 transmission from mother to infant [65].

HIV induces $\beta$-defensin- 2 and -3 in human oral epithelial cells, which exhibit strong anti-HIV activity [66] due to the direct antiviral effect or competition for the chemokine RECEPTORS that HIV uses to enter the cell [67]. Mother-to-child transmission of HIV is the main source of pediatric AIDS. There is a significant relationship between genetic variants of $\beta$-defensin-1 gene, viral load, and mother-to-child 
TABle 4. Human defensins

\begin{tabular}{|c|c|c|}
\hline Defensins & Cell types & Characteristics \\
\hline \multicolumn{3}{|l|}{$\alpha$-Defensins } \\
\hline HNP1-HNP4 & Neutrophils & $\begin{array}{l}\text { Broad spectrum of antimicrobial activity, chemo- } \\
\text { attractant for monocytes, T cells and dendritic cells }\end{array}$ \\
\hline HD5-6 & Intestinal tract & $\begin{array}{l}\text { Propeptide released by Paneth cells. Converted to } \\
\text { the active form by trypsin }\end{array}$ \\
\hline \multicolumn{3}{|l|}{$\beta$-Defensins } \\
\hline hBD-1 & $\begin{array}{l}\text { Keratinocytes, respiratory epithelia, } \\
\text { urogenital tract }\end{array}$ & Weak antimicrobial activity \\
\hline hBD-2 & $\begin{array}{l}\text { Keratinocytes, respiratory epithelia, } \\
\text { intestinal tract }\end{array}$ & $\begin{array}{l}\text { Active against Gram-negative bacteria and fungi, } \\
\text { chemoattractant for dendritic and T cells, human } \\
\text { neutrophils and mast cells }\end{array}$ \\
\hline hBD-3 & Keratinocytes, respiratory epithelia & Broad spectrum of antimicrobial activity \\
\hline hBD-4 & Keratinocytes, respiratory epithelia & $\begin{array}{l}\text { Activity against } P \text {. aeruginosa, } E \text {. coli and Gram- } \\
\text { positive bacteria }\end{array}$ \\
\hline
\end{tabular}

transmission of HIV. In mothers, the -52GG genotype is associated with low levels of HIV plasma viremia and a lower risk of maternal HIV transmission [68].

An antimicrobial peptide homologous to rhesus monkey circular mini-DEFENSINS ( $\delta$-DEFENSINS) has been prepared by solid-phase peptide synthesis and named retrocyclin. Retrocyclin has a remarkable ability to inhibit proviral DNA formation and to protect CD4 LYMPHOCYTES from in vitro infection by both T-tropic and M-tropic strains of HIV. Retrocyclin interferes with an early stage of HIV INFECTION and retrocyclin-like agents might be useful TOPICAL agents to prevent sexually acquired HIV infections. It is of interest that recent studies have shown that human cells possess the capability to make cyclic $\theta$-DEFENSINS [69].

DeFENSINS are known to exhibit inhibitory activity against several viruses. $\alpha$-DEFENSINS promote uptake of influenza virus by NEUTROPHILS, and human DEFENSINS 5 and 6 are effective in neutralizing influenza virus [70]. The expression of murine $\beta$-defensin was enhanced in influenza-infected lungs, trachea and nasal mucosa [71] and treatment of cell cultures with human neutrophil peptides soon after infection resulted in marked inhibition of influenza virus replication and viral protein synthesis [72]. BK virus is a polyomavirus that establishes a lifelong persistence in most humans. Studies have shown that human $\alpha$-DEFENSINS can inhibit BK virus infection [73], and inhibit adenovirus infection [74], and that $\alpha$-DEFENSINS and human $\beta$-defensin inhibited herpes simplex virus infection [75].

\section{Microbial-derived immunomodulators}

Cell walls of Gram-negative bacteria contain endotoxic LPS, which is a potent stimulator of the IMMUNE SYSTEM, even in nanogram quantities. Clinical application of ENDOTOXIN has, however, been hampered as it plays a major role in the pathophysiology of gram-negative bacterial sepsis. Concerted efforts have been made to modify ENDOTOXIN for possible therapeutic use in humans. Investigations on endotoxic LPS have led to the identification of lipid A as an important constitu- 
ent of the ENDOTOXIN molecule capable of exhibiting various immunopharmacological activities of the intact bacterial LPS. During the last few decades, selective reduction of the toxicity of ENDOTOXIN, while retaining its beneficial adjuvant property, has been achieved by effective chemical treatment and by synthesis of non-toxic lipid A analogues.

\section{Monophosphoryl lipid A}

Many advances in our understanding the TLR RECEPTORS and associated agonists have been made in recent years. This has led to the engineering of a new generation of adjuvants that incorporate these agonists for prophylactic and therapeutic vaccines. LPS (ENDOTOXIN) is a specific agonist of TLR4 but is too toxic for use in humans. Monophosphoryl lipid A (MPL) is a detoxified derivative of LPS isolated from the Gram-negative bacterium Salmonella minnesota and has been shown to be also a TLR4 agonist. MPL promotes IFN- $\gamma$ production and skews the immune response toward a Th1 profile [76] (Fig.8).

Formalin-inactivated RSV vaccine induces an immunopathological response that leads to disease enhancement upon RSV infection of those previously vaccinated. Vaccine containing MPL dramatically reduced the levels of Th1 and Th2 CYTOKINES in response to RSV challenge [77]. Prophylactic administration of MPL has been shown to mitigate the sepsis syndrome by reducing chemokine production of pulmonary and hepatic MIP-1 $\alpha$, MIP-1 $\beta$, MIP-2, and MCP-1 mRNA and attenuating the production of proinflammatory CYTOKINES. MPL has been used as an adjuvant with toxoplasmal, leishmanial, malarial, and tuberculosis ANTIGENS in preclinical studies.

Aluminum salts have long been used as adjuvants. They promote ANTIBODY production and are more biased towards a Th2 response. The particulate structure of aluminum salts facilitates formation of

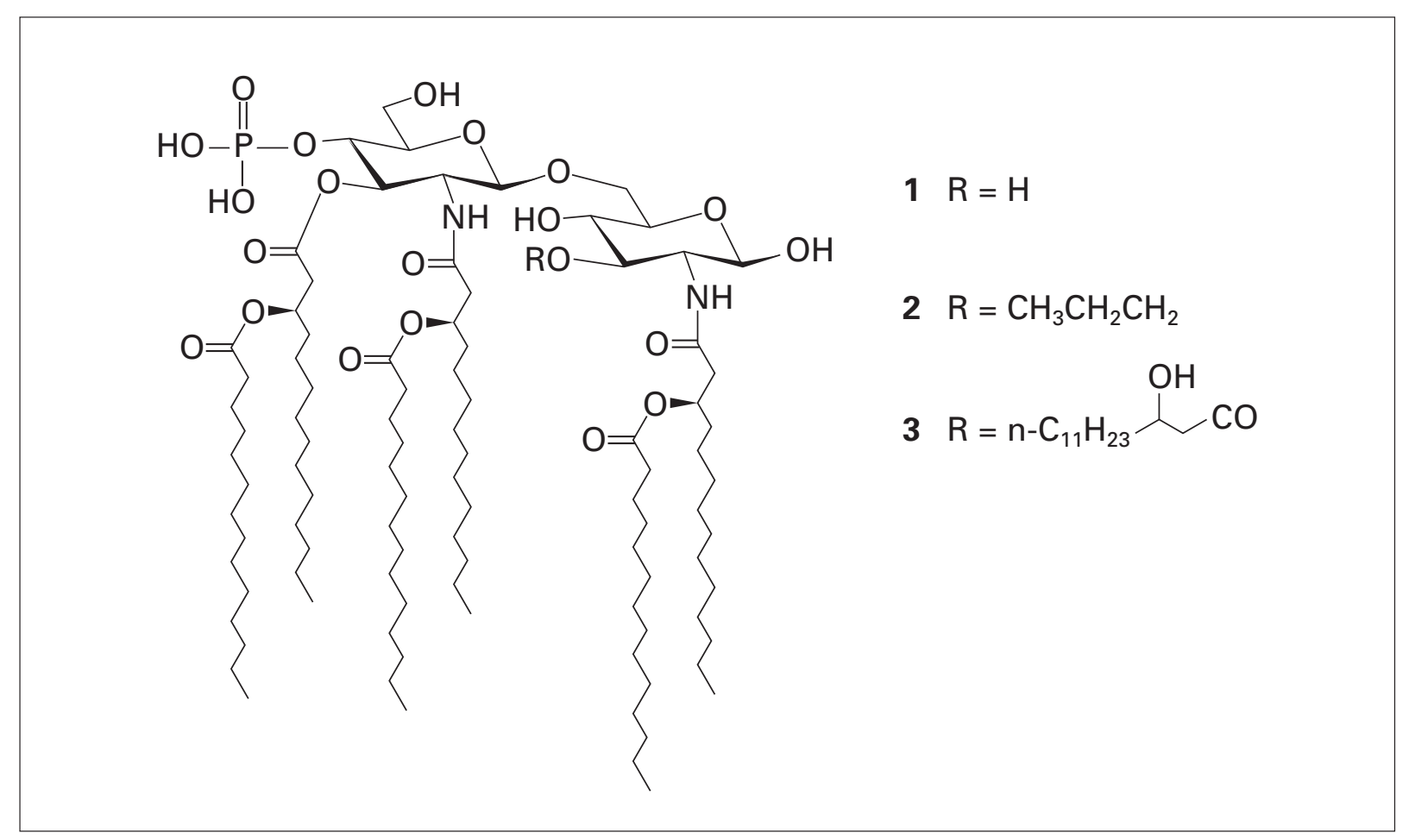

Figure 8. StRUCTURE OF MONOPHOSPHORYL LIPID A 
an antigen depot at the injection site for a sustained response.At the molecular level, aluminum adjuvants have been shown to stimulate Nlrp3, a component of the INFLAMMASOME.The multifunctional INFLAMMASOME can lead to processing of proforms of cytokine IL-18 or IL-1 $\beta$. Alum alone is not able to induce the transcription of IL-18 or IL-1 $\beta$ genes in antigen-presenting cells (APCs) and needs additional pretreatment of the APC with TLR ligands such as MPL.

The Adjuvant System 04 (AS04), licensed for use in humans, consists of MPL (3-O-desacyl-4'monophosphoryl lipid A) adsorbed onto a particulate form of aluminum salt. It has been developed by GlaxoSmithKline BıLogicals as a new generation of adjuvants. MPL and aluminum salt apparently synergize in AS04 to produce elevated levels of IL-18 or IL-1 3 .AS04 is currently used in two licensed vaccines, Fendrix against HBV and Cervarix against HPV-16 and HPV-18 cervical cancer. A third vaccine against herpes simplex 2 virus is in phase III clinical trials.

\section{Microbial immunomodulators}

\section{Probiotics}

PROBIOTICS are living microorganisms that are ingested by the host on purpose for improving intestinal microbial balance and promoting health. The global interest in innovative PROBIOTICS as a NATURAL way of restoring the body's normal MICROBIOTA, as an alternative way of preventing or treating infectious diseases without side effects and for general wellbeing, has increased dramatically since the end of the 1990s and the trend remains unbroken. Several probiotic products are available as freeze-dried, lyophilized or heat-dried culture supernatant capsules, and as fortifiers of dairy foods (e.g., yogurt, milk, kefir, ice cream or cheese).

Several immune functions, such as PHAGOCYTOsIS, NK cell activity and mucosal Ig A production (especially in children), can be improved by some probiotic bacteria (see also chapter $\mathrm{C} 8$ ). The major Lactobacillus species present in the human gastrointestinal mucosa, $L$. plantarum, $L$. rhamnosus and L. paracasei, have been found to be potent stimulators of IL-12 [78]. Probiotics, including lactobacilli and bifidobacteria, administered to children can reduce incidence and duration of diarrhea. Bifidobacterium breve has been shown to augment ANTIBODY production and induce significant reduction in the frequency of rotavirus shedding in stool samples of infants [79]. Probiotic supplementation can reduce the risk of travelers' diarrhea in adults [80]. Whole microbes such as Lactobacillus casei, Bifidobacterium species and Saccharomyces boulardii have been used successfully to prevent antibiotic-associated diarrhea, and to treat other diarrheal illnesses caused by bacteria [81]. The beneficial bacterial flora present in the human body can be destroyed by antibiotic treatment and permits overgrowth of pathogenic bacteria. Antibiotics are designed to attack specific bacterial pathogens but, in the process, indiscreetly reduce the number of beneficial human MICROBIOTA that is part of the gut-associated lymphatic system [82]. Thus, supporting normal flora with live microorganisms can confer a beneficial health effect [83].

Probiotic lactobacilli can improve urogenital health by immune modulation, pathogen displacement and creation of conditions that are less conducive to proliferation of pathogens [84]. PROBIOTICS have been used for treating candidal vaginitis and urinary tract infections. Bacterial vaginosis is a common condition that recurs frequently in premenopausal women. It adversely affects women's lives, and is associated with several complications including increased risk of sexually transmitted infections and $\mathrm{HIV}$, and even adverse pregnancy outcome. It is characterized by depletion of the indigenous lactobacilli. The use of PROBIOTICS to populate the vagina and prevent or treat infection has shown EFFICACY, including supplementation of antimicrobial treatment to improve cure rates and prevent recurrences [85]. Probiotic lactobacilli can provide benefits to women being treated with antibiotics $[85,86]$. Urinary tract infection in children is common (5-10\%) and recurs in $10-30 \%$. Probiotics have also been used in children [87] and have been shown to reduce febrile illness caused by the urinary tract infection [88]

PRoBiotics may have a beneficial effect on the severity and duration of symptoms of respiratory infections but do not appear to reduce their incidence [89], and probiotic supplementation may 
prevent the spread of infection throughout the respiratory tract [90]. Risk of early acute otitis media and antibiotic use and the risk of recurrent respiratory infections during the first year of life may be reduced by PROBIOTICS [91].

Prebiotics are non-digestible food ingredients that confer benefits upon host well-being and health, whereas synergistic combinations of pro- and PREBIOTICS are called synbiotics. Treatment with synbiotics has been reported to significantly decrease the risk for sepsis by bloodstream infections [92]. It is interesting that the intestinal MICROBIOTA differs in infants who later develop allergic diseases, and feeding PROBIOTICS to infants at risk has been shown to reduce their rate of developing eczema [93]. Lactobacilli and bifidobacteria have been reported to reduce risk and severity of allergic disease, particular atopic dermatitis [80].

\section{Bacterial extracts}

BACTERIAL EXTRACTS have been widely used as immunomodulators to prevent recurrent infections of the upper and lower respiratory tract, particularly in children. They are comprised of common bacterial respiratory pathogens found in the respiratory tract. Several preparations containing bacterial lysates (e.g., Broncho-Munal ${ }^{\circledR}$, Broncho-Vaxom ${ }^{\circledR}$, Imocur ${ }^{\circledR}$, Lui$\left.\operatorname{vac}^{\circledR}\right)$ are licensed for use in Europe. Such preparations are, however, regarded with scepticism by many authorities who question their medicinal value.

A large body of primary literature exists on placebo-controlled and double-blind clinical trials that have been conducted with these agents. Patients, most often children, having recurrent episodes of infections of the respiratory tract and of the ear, nose and throat have been treated with oral bacterial lysates. In most cases, the frequency and the severity of infections were reported to be reduced and both the physician and the patient considered the treatment to be beneficial. It is of interest that many studies have reported a decrease in antibiotic consumption in bacterial lysate-treated patients and a reduction in the number and duration of hospitalizations $[94,95]$. A multicenter study with the oral bacterial lysate immunomodulator LW 50020, involving
4965 recurrent respiratory tract infection patients in 14 countries in Europe, Latin America, and Asia, has been conducted.An overall reduction of at least $50 \%$ in the number, severity, and duration of respiratory tract infections, the number of antibiotic and symptomatic treatments, and the number of days absent from school or work was reported [96].Hemodialysis patients suffer from several immune defects, which increase their risk of developing bacterial infections, particularly of the respiratory tract. In a double-blind placebo-controlled prospective study, oral IMMUNOTHERAPY with an immunomodulating bacterial extract significantly reduced the number of patients with respiratory tract infections and, consequently, the number of antibiotic treatment courses [97].

Mucosal immunization strategies able to induce secretory IgA for protection of mucosal surfaces and systemic immunity to pathogens invading the mucosal surface of the host are currently of great interest in the field of infectious diseases. The current concept of the mucosal IMMUNE SYSTEM postulates that stimulation of the gut-associated lymphoid tissue (GALT) can lead to the induction of a generalized response by the whole mucosal-associated lymphoid tissue. LYMPHOCYTES that have been sensitized to the antigen in the GALT migrate via the blood to mucosal tissues to generate antigen-specific secretory IgA ANTIBODIES, which play a key role in protection against pathogens invading mucosal surfaces [98]. Bacterial lysates such as Broncho-Vaxom ${ }^{\circledR}$ have been shown to increase IgA concentrations [99]. Earlier studies conducted in 1990s and early 2000s already showed that such preparations can enhance the production of diverse CYTOKINES such as IL-1, IL-12, IFN- $\gamma$, stimulate NK cells, induce B lymphocyte proliferation and activate phagocytic activity of MACROPHAGES $[99,100]$. The main problem with the use of BACTERIAL EXTRACTS may be cutaneous eruptions, itching and increased risk of lower urinary tract infections.

\section{Summary and perspective}

Preventing existing and emerging infectious diseases is a multidisciplinary and multifaceted endeavor.The 
traditional treatment of infections has focused on antimicrobial agents and on the induction of specific immune defenses. The appeal of immunomodulators is inherent in modes of action that are distinctly different from the direct microbicidal action of established antibiotic, antiviral, antifungal and antiparasitic drugs. The past few years have witnessed an explosion of scientific and clinical advances in the field of immunomodulator biology and therapy.There has been considerable interest in the therapeutic use of biologically manufactured CYTOKINES and cytokine inhibitors in infectious diseases, chronic inflammatory conditions and cancer. The immune-based therapies in combination with antimicrobial drugs, such as IFNs and ribavirin for viral hepatitis, especially, have attracted attention. A significant level of knowledge of the structure-activity relationships of CHEMOKINES has been amassed. Recent research has elucidated the mechanisms underlying the inhibitory activity of CHEMOKINES and has been instrumental in the rational design of anti-HIV chemokine analogues. Activation of innate non-antigen-specific host defenses by recently recognized immunomodulatory agents such as CpG DNA will increasingly find a beneficial role in the prevention of infections. TLR agonists such as MPL are being increasing used. The ongoing and upcoming trials of immunomodulatory agents should provide a wealth of information on clinical and safety matters. It is now also possible to control the deleterious overproduction of INFLAMMATORY CYTOKINES observed in certain disease states with several immunomodulatory agents. The potential market involving CYTOKINES is enormous and is poised to grow steadily. As an example, industry analysts estimate that successful CCR5 drugs for HIV and other disease states could generate sales of $\$ 500-700$ million a year. It is noteworthy that over 60 biotechnology protein drugs, including the RECOMBINANT proteins and MONOCLONAL ANTIBODIES that are currently available, represent over a quarter of the drugs recently introduced worldwide.

Discovery of new and continued development of diverse immunomodulators could complement established therapies. A greater understanding of the underlying molecular MECHANISMS OF ACTION should enable their future development. The goal still remains to convert the manifold advances made in the immunostimulants field into clinically applicable therapies. A diverse array of structures is available and it seems reasonable to expect that data from relevant infectious disease models will eventually lead to exciting breakthroughs. New methodologies have the potential to identify novel targets and foster the development of individually tailored immunomodulatory drug treatments.

\section{Selected readings}

Fallon P. Pathogen-Derived Immunomodulatory Molecules. Austin: Landes Biosciences co-published with Springer, Heidelberg, 2009: 1-202

\section{Recommended websites}

http://www.who.int/csr/disease/en/ http://www.emea.europa.eu/pdfs/human/antimicrobial_ resistance/EMEA-576176-2009.pdf

http://www.thebody.com/index.html

http://www.copewithcytokines.de/cope.cgi

http://www.sabiosciences.com/newsletter/PATHWAYS 07_TLR.pdf

\section{References}

1 Taylor PW,Stapleton PD, Paul LJ. New ways to treat bacterial infections. Drug Discov Today 2002; 7: 1086-91

2 Amyes SGB. The rise in bacterial resistance is partly because there have been no new classes of antibiotics since the 1960s. Br Med J 2000; 320: 199-200

3 Hengel $\mathrm{H}$, Masihi KN. Combinatorial immunotherapies for infectious diseases. Int Immunopharmacol 2003; 3: 1-9

4 Kayser O, Masihi KN, Kiderlen AFNatural products and synthetic compounds as immunomodulators. Expert Rev Anti Infect Ther 2003; 1:319-35

5 Masihi KN. Immunomodulatory agents for prophylaxis and therapy of infections. Int J Antimicrob Agents 2000; 14: 181-91 
6 Masihi KN. Fighting infection using immunomodulatory agents. Expert Opin Biol Ther 2001; 1: 641-53

7 Luxon BA, Grace M, Brassard D, Bordens R. Pegylated interferons for the treatment of chronic hepatitis $\mathrm{C}$ infection. Clin Ther 2002; 24: 1363-83

8 Koliouskas D, Sidiropoulos I, Masmanidou M, Dokas S, Ziakas A. Comparative analysis of Peg-interferon alpha-2b and lamivudine in the treatment of chronic hepatitis B patients: preliminary results.J Hepatol 2002; 36: 237-38

9 Lau GK, Piratvisuth T, Luo KX, Marcellin P,Thongsawat $\mathrm{S}$, Cooksley $\mathrm{G}$ et al. Peginterferon Alfa-2a, lamivudine, and the combination for HBeAg-positive chronic hepatitis B. N Engl J Med 2005; 352: 2682-95

10 Villa E, Lei B, Taliani G, Graziosi A, Critelli R, Luongo M. Pretreatment with pegylated interferon prevents emergence of lamivudine mutants in lamivudine-naive patients: a pilot study. Antivir Ther 2009; 14: 1081-7

11 Hui CK, Lau GK. Peginterferon-alpha2a (40 kDa) (Pegasys) for hepatitis B. Expert Rev Anti Infect Ther 2005; 3 : 495-504

12 Goldstein AL, Goldstein AL. From lab to bedside: emerging clinical applications of thymosin alpha1. Expert Opin Biol Ther 2009; 9: 593-608

13 Sugahara S, Ichida T, Yamagiwa S, Ishikawa T, Uehara $\mathrm{K}$, Yoshida $\mathrm{Y}$ et al. Thymosin-alpha1 increases intrahepatic NKT cells and CTLs in patients with chronic hepatitis B. Hepatol Res 2002; 24: 346-54

14 Zhang YY, Chen EQ, Yang J, Duan YR, Tang H.Treatment with lamivudine versus lamivudine and thymosin alpha-1 for e antigen-positive chronic hepatitis B patients: a meta-analysis. Virol J 2009; 6: 63

15 Garaci E, Favalli C, Pica F, Sinibaldi VP, Palamara AT, Matteucci $C$ et al. Thymosin alpha 1: from bench to bedside. Ann NY Acad Sci 2007; 1112: 225-34

16 Pimstone NR, Canio JB, Chiang MH. Ribavirin/interferon $-2 \mathrm{~b}$ therapy is very effective in the treatment of chronic hepatitis $\mathrm{C}$ genotype 2 and 3 patients who have failed to respond virologically to IFN monotherapy. Gastroenterology 2001; 120: A-382

17 Rajender R, Modi MW, Pedder S. Use of peginterferon alfa-2a (40 KD) [Pegasys(R)] for the treatment of hepatitis C.Adv Drug Deliv Rev 2002; 54: 571-86

18 Welch W,Foote M.The use of Filgrastim in AIDS-related neutropenia.J Hematother Stem Cell Res 1999; Suppl 1: S9-16

19 Kuritzkes DR, Parenti D, Ward DJ, Rachlis A, Wong RJ,
Mallon KP et al. Filgrastim prevents severe neutropenia and reduces infective morbidity in patients with advanced HIV infection: results of a randomized, multicenter, controlled trial. G-CSF 930101 Study Group. AIDS 1998; 12: 65-74

20 Dubreuil-Lemaire ML, Gori A, Vittecoq D, Panelatti G, Tharaux F, Palisses $\mathrm{R}$ et al. Lenograstim for the treatment of neutropenia in patients receiving ganciclovir for cytomegalovirus infection: a randomised, placebocontrolled trial in AIDS patients. Eur J Haematol 2000; 65: $337-43$

21 Rodriguez-Adrian LJ, Grazziutti ML, Rex JH, Anaissie EJ. The potential role of cytokine therapy for fungal infections in patients with cancer: is recovery from neutropenia all that is needed? Clin Infect Dis 1998; 26: 1270-78

22 Quinn TC, Overbaugh J. HIV/AIDS in women: an expanding epidemic. Science 2005; 308: 1582-83

23 Heeney JL. The critical role of $\mathrm{CD}\left(^{+}\right)$T-cell help in immunity to HIV. Vaccine 2002; 20: 1961-63

24 Dragic T. An overview of the determinants of CCR5 and CXCR4 co-receptor function. J Gen Virol 2001; 82: 1807-14

25 Lehner T. The role of CCR5 chemokine ligands and antibodies to CCR5 coreceptors in preventing HIV infection. Trends Immunol 2002; 23: 347-51

26 Kazmierski WM, Boone L, Lawrence W, Watson C, Kenakin T. CCR5 chemokine receptors: gatekeepers of HIV-1 infection. Curr Drug Targets Infect Disord 2002; 2: 265-78

27 Wetzel MA, Steele AD, Henderson EE, Rogers TJ. The effect of X4 and R5 HIV-1 on C, C-C, and C-X-C chemokines during the early stages of infection in human PBMCs. Virology 2002; 292: 6 -15

28 Fernandez EJ, Lolis E. Structure, function, and inhibition of chemokines. Annu Rev Pharmacol Toxicol 2002 ; $42: 469$-99

29 Lusso P.HIV and chemokines: implications for therapy and vaccine. Vaccine 2002; 20: 1964-67

30 Onuffer JJ, Horuk R. Chemokines, chemokine receptors and small-molecule antagonists: recent developments. Trends Pharmacol Sci 2002; 23: 459-67

31 Proudfoot AE, Power CA, Rommel C, Wells TN. Strategies for chemokine antagonists as therapeutics. Semin Immunol 2003; 15: 57-65

32 Princen K, Hatse S, Vermeire K, Aquaro S, De Clercq $\mathrm{E}$, Gerlach LO et al. Inhibition of human immuno- 
deficiency virus replication by a dual CCR5/CXCR4 antagonist.J Virol 2004; 78: 12996-13006

33 Hendrix CW, Flexner C, MacFarland RT, Giandomenico C, Fuchs EJ, Redpath E et al. Pharmacokinetics and safety of AMD-3100, a novel antagonist of the CXCR-4 chemokine receptor, in human volunteers. Antimicrob Agents Chemother 2000; 44: 1667-73

34 De CE. Potential clinical applications of the CXCR4 antagonist bicyclam AMD3100. Mini Rev Med Chem 2005; 5: 805-24

35 Amella CA, Sherry B, Shepp DH, Schmidtmayerova H. Macrophage inflammatory protein 1alpha inhibits postentry steps of human immunodeficiency virus type 1 infection via suppression of intracellular cyclic AMP.J Virol 2005; 79: 5625-31

36 Biragyn A, Belyakov IM, Chow YH, Dimitrov DS, Berzofsky JA, Kwak LW. DNA vaccines encoding human immunodeficiency virus-1 glycoprotein 120 fusions with proinflammatory chemoattractants induce systemic and mucosal immune responses. Blood 2002; 100: 1153-59

37 Rusconi S, La Seta C, Citterio P, Bulgheroni E, Croce F, Herrmann SH et al. Combination of CCR5 and CXCR4 inhibitors in therapy of human immunodeficiency virus type 1 infection: in vitro studies of mixed virus infections.J Virol 2000; 74: 9328-32

38 Gaertner H, Cerini F, Escola JM, Kuenzi G, Melotti A, Offord R et al. Highly potent, fully recombinant antiHIV chemokines: reengineering a low-cost microbicide. Proc Natl Acad Sci USA 2008; 105: 17706-11

39 Ham AS, Cost MR, Sassi AB, Dezzutti CS, Rohan LC. Targeted delivery of PSC-RANTES for HIV-1 prevention using biodegradable nanoparticles. Pharm Res 2009; 26: 502-11

40 Gaertner H, Offord R, Botti P,Kuenzi G, Hartley O. Semisynthetic analogues of PSC-RANTES, a potent anti-HIV protein. Bioconjug Chem 2008; 19: 480-49

41 Ting PT, Koo JY. Use of etanercept in human immunodeficiency virus (HIV) and acquired immunodeficiency syndrome (AIDS) patients. Int J Dermatol 2006; 45: 689-92

42 Johnson L, Jarvis JN, Wilkins EG, Hay PE. Thalidomide treatment for refractory HIV-associated colitis: a case series. Clin Infect Dis 2008; 47: 133-6

43 Stary G, Kohrgruber N, Herneth AM, Gaiger A, Stingl G, Rieger A. Complete regression of HIV-associated multi- centric Castleman disease treated with rituximab and thalidomide. AIDS 2008; 19; 22: 1232-34

44 Listing J, Strangfeld A, Kary S, Rau R, von Hinueber U, Stoyanova-Scholz $\mathrm{M}$ et al. Infections in patients with rheumatoid arthritis treated with biologic agents. Arthritis Rheum 2005; 52: 3403-12

45 Strangfeld A, Listing J. Infection and musculoskeletal conditions: Bacterial and opportunistic infections during anti-TNF therapy. Best Pract Res Clin Rheumatol 2006; 20: 1181-95

46 Tsiodras S, Samonis G, Boumpas DT, Kontoyiannis DP. Fungal infections complicating tumor necrosis factor alpha blockade therapy. Mayo Clin Proc 2008; 83: 181-94

47 Gao H, Evans TW, Finney SJ. Bench-to-bedside review: sepsis, severe sepsis and septic shock - does the nature of the infecting organism matter? Crit Care 2008; $12: 213$

48 Lynn M, Rossignol DP,Wheeler JL, Kao RJ, Perdomo CA, Noveck R et al. Blocking of responses to endotoxin by E5564 in healthy volunteers with experimental endotoxemia. J Infect Dis 2003; 187: 631-39

49 Stanley MA. Imiquimod and the imidazoquinolones: mechanism of action and therapeutic potential. Clin Exp Dermatol 2002; 27: 571-77

50 Alignani D, Maletto B, Liscovsky M, Ropolo A, Moron G, Pistoresi-Palencia MC. Orally administered OVA/CpGODN induces specific mucosal and systemic immune response in young and aged mice. J Leukoc Biol 2005; 77: 898-05

51 Weeratna RD, Brazolot Millan CL, McCluskie MJ, Davis HL. CpG ODN can re-direct the Th bias of established Th2 immune responses in adult and young mice. FEMS Immunol Med Microbiol 2001; 32: 65-71

52 Krieg AM, Davis HL. Enhancing vaccines with immune stimulatory CpG DNA. Curr Opin Mol Ther 2001; 3: $15-24$

53 Cooper CL, Davis HL, Morris ML, Efler SM, Adhami MA, Krieg AM et al. CPG 7909, an immunostimulatory TLR9 agonist oligodeoxynucleotide, as adjuvant to EngerixB HBV vaccine in healthy adults: a double-blind phase I/II study.J Clin Immunol 2004; 24: 693-701

54 Vicari AP,Schmalbach T, Lekstrom-Himes J, Morris ML, Al-Adhami MJ, Laframboise C et al. Safety, pharmacokinetics and immune effects in normal volunteers of CPG 10101 (ACTILON), an investigational synthetic 
toll-like receptor 9 agonist. Antivir Ther 2007; 12: 741-51

55 Jenssen H, Hamill P, Hancock RE. Peptide antimicrobial agents. Clin Microbiol Rev 2006; 19: 491-11

56 Brown KL, Hancock RE. Cationic host defense (antimicrobial) peptides. Curr Opin Immunol 2006; 18: 24-30

57 Kruse T, Kristensen HH. Using antimicrobial host defense peptides as anti-infective and immunomodulatory agents. Expert Rev Anti Infect Ther 2008; 6: 887-95

58 Hancock RE, Sahl HG. Antimicrobial and host-defense peptides as new anti-infective therapeutic strategies. Nat Biotechnol 2006; 24: 1551-57

59 Holzl MA, Hofer J, Steinberger P, Pfistershammer K, Zlabinger GJ. Host antimicrobial proteins as endogenous immunomodulators. Immunol Lett 2008; 119: $4-11$

60 Scott MG, Dullaghan E, Mookherjee N, Glavas N, Waldbrook M, Thompson A et al. An anti-infective peptide that selectively modulates the innate immune response. Nat Biotechnol 2007; 25: 465-72

61 Bowdish DM, Davidson DJ, Hancock RE. Immunomodulatory properties of defensins and cathelicidins. Curr Top Microbiol Immunol 2006; 306: 27-66

62 Lehrer RI, Ganz T. Defensins of vertebrate animals. Curr Opin Immunol 2002; 14: 96-102

63 Furci L, Sironi F, Tolazzi M, Vassena L, Lusso P. Alphadefensins block the early steps of HIV-1 infection: interference with the binding of gp120 to CD4.Blood 2007; 109: 2928-35

64 Trabattoni D, Caputo SL, Maffeis G, Vichi F, Biasin M, Pierotti $\mathrm{P}$ et al. Human alpha defensin in HIV-exposed but uninfected individuals. $J$ Acquir Immune Defic Syndr 2004; 35: 455-63

65 Kuhn L, Trabattoni D, Kankasa C, Semrau K, Kasonde $\mathrm{P}$, Lissoni $\mathrm{F}$ et al. Alpha-defensins in the prevention of HIV transmission among breastfed infants. J Acquir Immune Defic Syndr 2005; 39: 138-42

66 Zapata W, Rodriguez B, Weber J, Estrada H, QuinonesMateu ME et al. Increased levels of human betadefensins mRNA in sexually HIV-1 exposed but uninfected individuals. Curr HIV Res 2008; 6: 531-38

67 Garzino-Demo A. Chemokines and defensins as HIV suppressive factors: an evolving story. Curr Pharm Des 2007; 13: 163-72

68 Ricci E, Malacrida S, Zanchetta M, Montagna M, Giaquinto C, De RA. Role of beta-defensin-1 polymor- phisms in mother-to-child transmission of HIV-1. $J$ Acquir Immune Defic Syndr 2009; 51: 13-19

69 Venkataraman N, Cole AL, Ruchala P,Waring AJ, Lehrer RI, Stuchlik O et al. Reawakening retrocyclins: ancestral human defensins active against HIV-1. PLoS Biol 2009; 7: e95

70 Doss M, White MR, Tecle T, Gantz D, Crouch EC, Jung G et al. Interactions of alpha-, beta-, and theta-defensins with influenza A virus and surfactant protein D. $J$ Immunol 2009; 182: 7878-87

71 Chong KT, Thangavel RR, Tang X. Enhanced expression of murine beta-defensins (MBD-1, $-2,-3$, and -4 ) in upper and lower airway mucosa of influenza virus infected mice. Virology 2008; 380: 136-43

72 Salvatore M, Garcia-Sastre A, Ruchala P, Lehrer RI, Chang T, Klotman ME. alpha-Defensin inhibits influenza virus replication by cell-mediated mechanism(s). $J$ Infect Dis 2007; 196: 835-43

73 Dugan AS, Maginnis MS, Jordan JA, Gasparovic ML, Manley K, Page R et al. Human alpha-defensins inhibit $\mathrm{BK}$ virus infection by aggregating virions and blocking binding to host cells. J Biol Chem 2008; 283: 31125-32

74 Smith JG, Nemerow GR. Mechanism of adenovirus neutralization by Human alpha-defensins. Cell Host Microbe 2008; 3: 11-19

75 Hazrati E, Galen B, Lu W, Wang W, Ouyang Y, Keller MJ et al.Human alpha- and beta-defensins block multiple steps in herpes simplex virus infection. $J$ Immunol 2006; 177: 8658-66

76 Didierlaurent AM, Morel S, Lockman L, Giannini SL, Bisteau M, Carlsen $\mathrm{H}$ et al. AS04, an aluminum saltand TLR4 agonist-based adjuvant system, induces a transient localized innate immune response leading to enhanced adaptive immunity. J Immunol 2009; 183: 6186-97

77 Boukhvalova MS, Prince GA, Soroush L, Harrigan DC, Vogel SN, Blanco JC. The TLR4 agonist, monophosphoryl lipid A, attenuates the cytokine storm associated with respiratory syncytial virus vaccine-enhanced disease. Vaccine 2006; 24: 5027-35

78 Hessle C, Hanson LA, Wold AE. Lactobacilli from human gastrointestinal mucosa are strong stimulators of IL-12 production. Clin Exp Immunol 1999; 116: 276-82

79 Yasui H, Shida K, Matsuzaki T, Yokokura T. Immunomodulatory function of lactic acid bacteria. Antonie Van Leeuwenhoek 1999; 76: 383-89 
80 Lomax AR, Calder PC. Probiotics, immune function, infection and inflammation: a review of the evidence from studies conducted in humans. Curr Pharm Des 2009; 15: 1428-1518

81 Minocha A. Probiotics for preventive health. Nutr Clin Pract 2009; 24: 227-41

82 Rohde CL, Bartolini V, Jones N. The use of probiotics in the prevention and treatment of antibiotic-associated diarrhea with special interest in Clostridium difficileassociated diarrhea. Nutr Clin Pract 2009; 24: 33-40

83 Sanz Y, Nadal I, Sanchez E. Probiotics as drugs against human gastrointestinal infections. Recent Pat Antiinfect Drug Discov 2007; 2: 148-56

84 Reid G. Probiotic lactobacilli for urogenital health in women.J Clin Gastroenterol 2008; 42 Suppl 3: S234-36

85 Cribby S, Taylor M, Reid G.Vaginal microbiota and the use of probiotics. Interdiscip Perspect Infect Dis 2008; 2008: 256490

86 Martinez RC, Franceschini SA, Patta MC, Quintana SM, Gomes BC, De Martinis EC et al. Improved cure of bacterial vaginosis with single dose of tinidazole $(2$ g), Lactobacillus rhamnosus GR-1, and Lactobacillus reuteri RC-14: a randomized, double-blind, placebocontrolled trial. Can J Microbiol 2009; 55: 133-38

87 Wallace B. Clinical use of probiotics in the pediatric population. Nutr Clin Pract 2009; 24: 50-59

88 Williams G, Craig JC. Prevention of recurrent urinary tract infection in children. Curr Opin Infect Dis 2009; 22: 72-76

89 Vouloumanou EK, Makris GC, Karageorgopoulos DE, Falagas ME. Probiotics for the prevention of respiratory tract infections: a systematic review. Int J Antimicrob Agents 2009; 34: 197-10

90 Tiollier E, Chennaoui M, Gomez-Merino D, Drogou C, Filaire E, Guezennec CY. Effect of a probiotics supplementation on respiratory infections and immune and hormonal parameters during intense military training. Mil Med 2007; 172: 1006-11

91 Rautava S, Salminen S, Isolauri E. Specific probiotics in reducing the risk of acute infections in infancy - a randomised, double-blind, placebo-controlled study. Br J Nutr 2009; 101: 1722-26

92 Giamarellos-Bourboulis EJ, Bengmark S, Kanellakopoulou K, Kotzampassi K. Pro- and synbiotics to control inflammation and infection in patients with multiple injuries.J Trauma 2009; 67: 815-21

93 Singh M, Ranjan DR. Probiotics for allergic respiratory diseases - Putting it into perspective. Pediatr Allergy Immunol 2009; DOI: 10.1111/j.1399-3038.2009.00921.x

94 Del-Rio-Navarro BE, Luis Sienra-Monge JJ, Berber A, Torres-Alcantara S, vila-Castanon L, Gomez-Barreto D. Use of OM-85 BV in children suffering from recurrent respiratory tract infections and subnormal IgG subclass levels. Allergol Immunopathol (Madr) 2003; 31: 7-13

95 Collet JP,Shapiro P,Ernst P,Renzi T, Ducruet T, Robinson A. Effects of an immunostimulating agent on acute exacerbations and hospitalizations in patients with chronic obstructive pulmonary disease. The PARI-IS Study Steering Committee and Research Group. Prevention of acute respiratory infection by an immunostimulant. Am J Respir Crit Care Med 1997; 156: 1719-24

96 Grevers G, Palacios OA, Rodriguez B, Abel S, van Aubel A. Treatment of recurrent respiratory tract infections with a polyvalent bacterial lysate: results of an open, prospective, multinational study. Adv Ther 2000; 17: $103-16$

97 Tielemans C, Gastaldello K, Husson C, Marchant A, Delville JP,Vanherweghem JL et al. Efficacy of oral immunotherapy on respiratory infections in hemodialysis patients: a double-blind, placebo-controlled study. Clin Nephrol 1999; 51: 153-60

98 Kang W, Kudsk KA. Is there evidence that the gut contributes to mucosal immunity in humans? J Parenter Enteral Nutr 2007; 31: 246-58

99 Huber M, Mossmann H, Bessler WG. Th1-orientated immunological properties of the bacterial extract OM85-BV.Eur J Med Res 2005; 10: 2309-17

100 Rozy A, Chorostowska-Wynimko J. Bacterial immunostimulants - mechanism of action and clinical application in respiratory diseases. Pneumonol Alergol Pol 2008; 76: 353-59 